\title{
FOREIGN COMMUNIST PROPAGANDA IN THE MATLS: A REPORT ON SOME PROBLEMS OF FEDERAL CENSORSHIP*
}

\author{
Murrax L. Schwartz † and James C. N. Paul $\ddagger$
}

\begin{abstract}
Little has been weritten of the activities of the federal govermment's progran for withholding from American addressees "foreign communist propaganda" mailed from abroad. In this Article, the second of a series of studies in the problems of postal censorship, the authors report on these activities, examine the legal bases for the operation, and weigh a mumber of legislative alternatives against the constitutional guaranty of free expression. An earlier study dealt zerith the censorship problems which arise from the exercise of the power to exclude obscene matter from the mails.
\end{abstract}

Since 1951, our Government has engaged in wholesale confiscation of publications mailed into this country from behind the Iron Curtain.

* This Article is based upon a study of "censorship" of the mails conducted under the auspices of the Institute of Legal Research of the University of Pennsylvania Law School. The study has been financed by the Fund for the Republic, Inc. The authors have acted as co-directors of the project. See, for a related study, Paul \& Schwartz, Obscenity in the Mails: A Conment on Some Problems of Federal Censorship, 106 U. PA. I. REv. 214 (1957).

Research for this project included, among other things, field investigations of postal and customs operations in Washington, New York, Philadelphia, Chicago, St. Paul, Minneapolis, Los Angeles and San Francisco, where officials responsible for enforcement of the laws under study were interviewed. The Post Office and Treasury Departments kindly furnished us in 1956 with an unofficial memorandum describing the legal bases and modus operandi of their program for exclusion of foreign communist propaganda. This titleless document is cited hereinafter as the Treasury-Post Office Memorandum. Many persons within Government have assisted us, and we should like to acknowledge particularly, in regard to this phase of our study, the help of Mr. Abe M. Goff, former Solicitor (later his title was changed to General Counsel) of the Post Office Department and of Mr. Irving Fishman, Deputy Collector of Customs of the Port of New York. Mr. Fishman has given us more time than we had any right to expect; while our report may seem critical of the program which he has done so much to implement, we should like to record here our high regard both for his sense of duty and his sensitivity to the civil liberties problems inherent in the operation over which he presides.

In an effort to learn more about the scope and effect of the Postal-Customs exclusionary program described herein, we have canvassed about sixty of the major research libraries of the United States. Nearly every library to which we wrote sent back replies, responding in full to a rather detailed questionnaire and frequently submitting copies of pertinent correspondence. We are indeed grateful for this help. To build our file of case instances reflecting enforcement of the Postal-Customs program, we submitted similar letter questionnaires to about 200 scholars, journalists, writers, and other persons and organizations who we thought might have had relevant experience. In addition we consulted the files of the American Civil Liberties Union for similar case histories. Except in a few instances where there has been prior publicity, we have not identified any individuals or institutions by name when we have referred to case histories. However, the case histories cited in this report are documented in the files of the Institute of Legal Research.

An excellent Note, Government Exclusion of Foreign Political Propaganda, 68 Harv. I. Rev. 1393 (1955), deals with the subject of this Article. We are glad to acknowledge our appreciation of and indebtedness to this work.

$\dot{i}$ Visiting Associate Professor of Law, University of California, Los Angeles.

$\ddagger$ Associate Professor of Law, University of Pennsylvania. 
United States officials have ruled that these publications, when they contain "foreign political propaganda," are "nonmailable": they violate a complex of legislation, composed of the Espionage Act ${ }^{1}$ and the Foreign Agents Registration Act. ${ }^{2}$

The logic of this ruling requires the confiscation of all "propaganda" mailed from any country, and on a few occasions over-zealous customs and postal men have pushed the program just that far. Their sieve of restraint has caught not only overt Communist propaganda, but also a pamphlet by a member of the British Parliament criticizing the position of the United States during the Guatemalan revolution of 1954, various pacifist materials from England, scientific works, geographies, novels and, mirabile dictu, quantities of an edition of the London Economist.

At the program's frustrating nadir, several years ago, one United States civil servant, working in a storage room in a big city post office, was given a Russian dictionary by harassed superiors and told to interpret bales of intercepted Russian publications to determine whether any contained "foreign political propaganda." Today things are different and better. The screening and impounding of mail from Iron Curtain countries goes on. But exemptions (of dubious validity in the strict legal sense) have been created so that persons who desire to receive publications of virtually any sort from Communist countries can get them-provided they do not import propaganda in quantity. The flow of mail from non-Iron Curtain countries is no longer subjected to screening for subversive "propaganda" content, except perhaps in cases where it emanates from known Communist controlled sources.

There has been little open discussion of this program-which is, today, in essence, an operation to keep Communists abroad from using our postal service to disseminate their propaganda on a wholesale basis. Published rules do not fully explain the scope and procedures of the operation; responsible officials have, in the past, been reluctant to discuss it, at times even before congressional committees. Until very recently only a select group (to whom publications are regularly addressed) have been directly told that there is a program calling for interception and destruction of Iron Curtain mailings-let alone for their release upon request, pursuant to the exceptions to the exclusionary program which the Government has created.

The Government has been successful to date in avoiding lawsuits, and it seems clear that Postal, Customs and Justice Department officials have no desire to test their legal authority to do what they are doing.

1. Ch. 30, 40 Stat. 217 (1917) (codified in scattered sections of 18 U.S.C.).

2. 52 Stat. 631 (1938), as amended, 22 U.S.C. $\$ \$ 611-21$ (Supp. V, 1958). 
Importuned at intervals, Congress has still failed to enact legislation which would clearly authorize this operation or any workable alternative.

But the facts and dangers of the cold war remain stark. Under present conditions the Government probably will not cease this censorship unless required by Congress or the courts. So, year by year, thousands of publications containing "foreign political propaganda"-primarily Communist propaganda-are intercepted on arrival in this country and destroyed. Precisely how much is destroyed and precisely what is destroyed (e.g., by title) remain somewhat a mystery because security policies censor much information on this censorship program. With the possible exception of World War II, there has been no similar broad-gauged effort to confiscate so much hostile "propaganda."

The justification of the program appears to be twofold: to protect the American public from being swamped and seduced by subversive material; and to prevent the United States from subsidizing propaganda efforts by totalitarian enemies whom we are spending billions, at deficits, to combat.

Whatever the merits of these purposes, the program should not be based on the attenuated interpretation of the existing legislation now invoked to support it. Congress should review the problem of controlling this Communist propaganda and either abolish today's program calling for its exclusion or authorize some alternative countermeasures which will insure more appropriate safeguards to the interests of freedom.

\section{Origins of the Program: In Law and History}

Throughout our history, the United States Government has periodically utilized its physical control over the mails to suppress propaganda deemed subversive.

Federalist officials seized newspapers and tracts-both domestic and foreign-when they espoused too much Jacobin ideology and French revolutionary sympathy. ${ }^{3}$

In pre-Civil War days, southern postmasters frequently refused to carry "incendiary" abolitionist materials. Congress never authorized this wholesale confiscation; indeed, Congress once rejected a bill granting precisely the power, but top postal officials went on sanctioning the practice for years. And, in the 1850's, as North-South tensions increasingly strained fears and patience, the Attorney General openly

3. See, e.g., Miller, Crusis in FreEDOM 31, 126, 134, 187, 189 (1951). 
avowed the necessity and advised the legality of this suppression: suppose, wrote the astute, "doughface" Democrat, Mr. Caleb Cushing, some foreign power were to use the United States mails to stir up class hatreds and foment civil strife as a preliminary to forcible seizure of our sovereignty-would any one doubt the inherent power of the United States Government to stop the use of its own operation, the carriage of mail, to achieve the purpose? ${ }^{4}$

During World War I fear of subversion by propagandists using the mails recurred. German propaganda and later left wing propaganda was suppressed-and some of the suppression was never expressly authorized by any statute. ${ }^{5}$ In 1917 , by the Espionage Act, ${ }^{6}$ Congress outlawed mailings advocating treason or forcible resistance to our laws. These and other materials mailed in connection with "espionage" activities were never to be carried through the post; they were to be stopped in transit; thus, a power of censorship was bestowed. In 1930, Congress authorized more of this censorship, declaring that material advocating treason or insurrection should also be denied entry into the country, and customs officials were authorized to seize it for libeling wherever they found it. ${ }^{7}$

Yet none of these laws dealt with problems which began to agitate more and more Americans during the Thirties: the mass dissemination of propaganda by Nazis and Communists. These materials did not advocate overt treason; they were more subtle. They were also being mailed in vast volume throughout the country. Efforts to control their dissemination mark the origins of today's anti-Communist operation.

Congressional committees of varying membership and viewpoint became increasingly concerned because so much of this propaganda was prepared by foreign sources for dissemination here. They investigated, publicized and promoted bills of various sorts. ${ }^{8}$ Finally a select com-

4. See, e.g., H.R. Rep. No. 51, 37th Cong., 3d Sess. (1863) ; Rogers, The Postal Power of Congress, in 34 JoHNS HopkINS UNIVERSITY STUDIES IN HISTORICAL AND Political ScIENCE 103-16 (1916). See also Deutsch, Freedom of the Press and of the Mails, 36 Mick. L. Rkv. 703 (1938); Rogge, Congress Shall Make No Law, 56 MICH. L. REv. 331 (1958).

5. See United States ex rel. Milwaukee Social Democratic Publishing Co. v. Burleson, 255 U.S. 407 (1921); Chaffee, Free Speech IN The United STAtes (1941) ; cf. Rogers, supra note 4, at 118-19 (President Theodore Roosevelt ordered post office to exclude "anarchist" publications from mails notwithstanding the complete absence of any statute authorizing such action; Attorney General advised that action was legal).

6. Act of June 15, 1917, ch. 30, 40 Stat. 217.

7. Tariff Act, ch. 497, 46 Stat. 688 (1930).

8. For material reflecting the concern of congressional committees, see, e.g., H.R. REP. No. 2290, 72d Cong., 2d Sess. (1933) ; H.R. REP. No. 153, 74th Cong., 1st Sess. (1935) ; H.R. REP. No. 1381, 75th Cong., 1st Sess. (1937) ; S. REP. No. 1783, 75th Cong., 3d Sess. (1938). See also Hearings Before the Special House Committee on Un-American Activities, 73d Cong., 2d Sess. (1934). 
mittee produced a bill which Congress adopted in 1938: The Foreign Agents Registration Act. ${ }^{9}$

As the name implied, it was a registration statute. In essence the law said: Every "agent" of a "foreign principal" must file statements with the Secretary of State giving information about himself, his activities and his "foreign principal." "Foreign principal" meant practically everyone from an impersonal government to an individual who was not located in the United States. An "agent of a foreign principal" was defined equally broadly, including public-relations counsel, servant, representative, or attorney for a foreign principal or for any domestic organization subsidized by a foreign principal.

Failure of any "foreign agent" to register was a crime. But nowhere did the law authorize censorship of any materials mailed by agents. Indeed, as originally written, the statute made no reference to "propaganda" or any other type of materials. An unregistered disseminator who was an "agent" might be imprisoned for failing to reveal himself, but the act did not, in terms at least, permit stoppage of the things he sent through the post.

Thus, the act was intended to compel disclosure, not authorize censorship. It was simply a law designed to stop pollution of the "free market place of ideas" with nostrums promoted by undisclosed alien, totalitarian sources. Said the House Committee on the Judiciary: "We believe that the spotlight of pitiless publicity will serve as a deterrent to the spread of pernicious propaganda." 10

The anticipated "spotlight" failed to deter. In 1939 and 1941 the Dies Committee reported that tons of propaganda were coming in from Germany, Italy, Japan and Russia. Books, tracts, newspapers and similar matter were sent, often in quantity to individuals, schools, colleges, institutions, business houses, and other selected addressees apparently in the hope that these recipients would in some way promote further dissemination. Paradoxically there were few recorded registrations of foreign agents. Despite verbal blasts by committees headed by such capable publicists as Fish, McCormack and Dies, there were few prosecutions for failure to register. ${ }^{11}$

9. 52 Stat. 631 (1938), as amended, 22 U.S.C. \$\$611-21 (Supp. V, 1958) (frequently called the "McCormack Act," after the Select Committee's Chairman, Mr. McCormack of Massachusetts). See for its legislative history H.R. REP. No. 1381, 75th Cong., 1st Sess. (1937); S. REP. No. 1783, 75th Cong., 3d Sess. (1938).

10. H.R. Rep. No. 1381, 75th Cong., 1st Sess. (1937). See 83 Cong. Rec. 8021-22 (1938).

11. H.R. REP. No. 2, 76th Cong., $2 d$ Sess. (1939) ; H.R. REP. No. 1, 77th Cong., 1st Sess. (1942); 87 CoNG. REc. app. 4417-18 (1941); Institute of Living Law, Combatting Totalitarian Propaganda, The Method of Exposure, 10 U. CHI. L. REv. 107 (1943). 
Indeed, a defect in the law was unintentionally overlooked or obfuscated. The act failed to speak in terms to this serious problem: how should we deal with a Nazi propagandist who, physically, was not here, who sat in an office in Berlin with a list of United States addressees at his side to whom he mailed his material directly? There was no way of compelling this propagandist to register. There was no statute, no policy, no program in terms designed to publicize or check his activities.

By 1940 United States involvement in the Armageddon against Germany was on the increase. Yet alien propagandists abroad were stepping up their output, using United States Post Offices in the effort to foment racial antagonisms as well as undermine United States support for the beleaguered democracies. Post Office leaders reacted to the danger as they conceived it. They seized several large shipments of Nazi propaganda. Postmaster General Frank Walker then requested the opinion of Attorney General Robert H. Jackson-could he legally do what he had done? Yes, replied the Attorney General, coming up with an opinion containing an interweaving of assorted provisions of the United States Code to support the result. ${ }^{12}$

The Espionage Act, he noted, renders "nonmailable" not only treasonable materials, but also all material which violates its own section 22. That section imposes criminal penalties upon anyone who "in aid of any foreign government, knowingly and wilfully possesses or controls any property or papers used or designed or intended for use in violating any penal statute. . . . "13 Section 22 thus appears to embrace the entire federal penal code, provided the activity (1) involves the knowing "possession of papers intended" for criminal use, and (2) is "in aid of a foreign government." So, if "papers" are possessed in violation of section 22 , they are "nonmailable." Continued the Attorney General: If any propaganda were mailed by a nonregistered agent in this country, this activity (i.e., acting as an agent, here, without registering) would constitute a violation of the penal code of the kind which would make the propaganda "nonmailable" through recourse to section 22 . Then followed the tour de force of the ruling - a neat feat of legal fiction-making-whereby foreign dissem-

12. 39 Ops. AtT'y Gen. 535 (1940). See 87 Cong. Rec. 1865, app. 831 (1941). Subsequently the Department of Justice advised the Bureau of Customs that publications entering the country other than by mail were subject to the same limitation on the theory that the importation of such material would be a violation of 18 U.S.C. $\$ 545$ (1952), as a "knowing" importation of "merchandise contrary to law." TreasuryPost Office Memorandum; cf. McGrath v. Kristensen, 340 U.S. 162, 176 (1950) (Jackson, J., concurring) (Justice Jackson commenting on opinion of Attorney General Jackson).

13. 18 U.S.C. $\S 957$ (1952). (Emphasis added.) 
inators, men who had never set foot on United States soil, became unregistered agents engaged in criminal activity here. Declared the Attorney General : The use of our mails by persons outside the United States for the purpose of committing an act which, if committed within the United States would constitute a violation of a criminal statute, renders them liable to the penalties of the statute. So the foreign disseminator, by using United States mail service becomes an unregistered agent here, and his propaganda piece becomes a "paper" which is "controlled" in violation of section 22, thereby rendering the matter "nonmailable" under the Espionage Act.

As a consequence of this ruling, postal and customs men were apparently authorized to intercept and destroy any material which either agency considered political propaganda in aid of a foreign government, sent from abroad by any person who, prima facie, would appear to be a foreign agent if he were here.

The ruling was backed by reasoning which was vulnerable. Overlooked was the fact that the purpose of the Registration Act was disclosure, not censorship. ${ }^{14}$ It is one policy to make criminal the failure of propagandists to register, but quite another to give an administrative agency unlimited discretion to confiscate their propaganda. It is going even further to give Government men a carte blanche power to seize all propaganda sent from abroad and designed to aid a foreign government-their.power to be limited only by the vague mandate that the sender be classifiable as an "agent."

Moreover, the Registration Act was designed to uncover domestic conduits for the propaganda of foreign nations-disclosure of the link between an agent operating here and his foreign backers. It was quite a stretch to say that Congress had also told officials of foreign governments and employees of foreign companies-men who had never set foot in this country-to file regular reports with our State Department setting forth "the terms and conditions of their contracts of employment" followed by a statement of their activities every six months, these statements to be public records. ${ }^{15}$

14. See text accompanying note 10 supra. See also Black, J., dissenting in Viereck v. United States, 318 U.S. 236, 251 (1943): "What emerged from extended Congressional investigations, hearings and deliberations was this Act, intended to provide an appropriate method to obtain information essential for the proper evaluation of political propaganda emanating from hired agents of foreign countries. As the House and Senate Committees considering the Bill said, it 'does not in any way impair the right of freedom of speech, or of a free press, or other constitutional rights.' Resting on the fundamental constitutional principle that our people, adequately informed, may be trusted to distinguish between the true and the false, the bill is intended to label information of foreign origin so that hearers and readers may not be deceived by the belief that the information comes from a disinterested source. Such legislation implements rather than detracts from the prized freedoms guaranteed by the First Amendment"

15. See note 70 infra. 
So the Attorney General's "opinion" was executive lawmaking in a grand manner. But after all the country was going into war. And with war came other forms of censorship: the channels of communication anywhere abroad were soon policed totally through enforcement of the Trading With the Enemy Act, ${ }^{16}$ through the activities of the Office of Censorship and other wartime operations. ${ }^{17}$ There was little impetus to challenge the Government about its program for dumping Nazi propaganda. And none was forthcoming.

In 1942 the Registration Act was substantially amended. ${ }^{18}$ Administration of its disclosure requirements was turned over to the Department of Justice. Registration statements were to contain more information. "Political propaganda" was defined broadly and "foreign agents" were required to label their "propaganda." The label was to explain that the-material was "propaganda," that the disseminator was an "agent," and that registration and dissemination did not indicate approval by the United States Government of his message. The transmittal of unlabeled propaganda through the mails by a foreign agent was declared unlawful. Penalties for violation were increased.

To put at rest any thought that the 1942 amendments in any way affected the Attorney General's opinion dealing with foreign propaganda mailed directly from foreign lands, the Department of Justice promulgated rule 50 (for the enforcement of the act). It reiterated the gist of Attorney General Jackson's 1940 ruling. ${ }^{19}$

The censorship operation based on that ruling was managed by postal and customs men, and it lasted until the end of the war. Then it lapsed. The necessity which was its real basis seemed to have ended.

Then the cold war turned hot in Korea; and, with warfare raging, international Communism commenced major propaganda drives all over the world. Into this country poured publications of all kinds produced in Moscow, Peiping, Prague, Warsaw and other Communist centers. ${ }^{20}$

16. 40 Stat. 416 (1917), as amended, 50 U.S.C. APP. $\$ \S 1-40$ (1952).

17. On wartime censorship generally, see Price, Governmental Censorship in Wartime, 36 AM. PoL. Scr. Rev. 837 (1942); Shriver \& Larson, Office of Censorship, 2 Bill of Rights L. Rev. 189 (1942). See the War Powers Acts, ch. 593, 55 Stat. 838 (1941), as amended, 50 U.S.C. ApP. $\$ \$ 601-20$ (1952); ch. 199, 56 Stat. 176 (1942), as amended, 50 U.S.C. APP. $\$ \S 633-45$ (1952); Exec. Order No. 8985, 6 Fed. Reg. 6625 (1941); U.S. Censorship Regulations, 81 Fed. Reg. 1644 (1943). Section 303 of the War Powers Act of 1941, supra, was repealed July 25, 1947. See ch. 327,61 Stat. 449 (1947).

18. Ch. 263, 56 Stat. 248 (1942). See H.R. ReP. No. 1547, 77th Cong., 1st Sess. (1941) ; S. REP. No. 913, 77th Cong., 1st Sess. (1941) ; 87 Cong. REc. 8906, $10022,10052,10055$ (1941).

19. The text of rule 50 appears in 28 C.F.R. $\$ 5.500$ (1955).

20. Discussion which follows in text of the origins of the program is based primarily on our interviews with the Solicitor of the Post Office Department and 
Varying in style, content and intellectual appeal, there were tracts and magazines containing panegyrics of life in Communist countries, extreme criticisms of life in the United States, appeals for peace and peace petitions, accusations and "documentary proof" of United States germ warfare and prisoner-of-war "atrocities" in Asia.

Vast quantities of foreign language newspapers and pamphlets were also coming in, apparently unsolicited and sent individually to persons of obvious foreign descent. Thus, Warsaw-published items were sent to obvious Polish-American addressees, and later investiga-. tions sustained the hunch of postal and customs officials that recipients in this class were recently naturalized or first generation citizens. On the West Coast there was a similar story, but here the appeal was in Chinese to Chinese-and many of these recipients apparently could read nothing but Chinese. These special patterns of propagandizing were particularly disturbing to the postal, customs and Justice Department men who commenced to organize United States resistance to the Communist propaganda deluge; since the beginning they have openly avowed their fear that this propaganda might have an impact on its recipients-if it were continuously delivered. There also appeared unusual quantities of books of every kind-songbooks, picture-books for children, texts for scholars. Some would seem innocent even to the most zealous anti-Communist; others were freighted with party doctrine and party line attacks on United States institutions and culture.

Thus, propaganda pieces of all varieties started coming in by the thousands. In the beginning no measurements of volume were made; none could be made without considerable burden. By March 1951, the Deputy Collector of Customs in New York had instituted a sixmonth check of Iron Curtain material of the "propaganda type" coming through New York: about 25,000 packages of mail had entered; a package often contained as many as 100 different pieces of propaganda. This volume increased steadily. And New York was only one

particularly with Mr. Irving Fishman, Deputy Collector of Curstoms of the Port of New York. Mr. Fishman is in charge of the Restricted Merchandise Division, has been active in the management of the program and is probably more familiar with its operation than anyone else in Government today. For published material on this subject, see, e.g., Hearings Before the Subcommittee To Investigate the Administration of the Internal Security Act and Other Internal Security Laws of the Sentate Committee on the Judiciary, 82d Cong., 1st Sess. 1-73 (1952); id., 83d Cong., 1st Sess. 19-24, 144-45, 223-56 (1953). For later, similar materials, see Hearings Before the Honse Committee on Un-American Activities, 84th Cong., 2d Sess. (1956) ; id., 85th Cong., 1st Sess. (1957) ; id., 85th Cong., 2d Sess. (1958). All of these hearings contain testimony by postal and customs officials, particularly $\mathrm{Mr}$. Fishman, outlining the history and development of today's program for the exclusion of Communist propaganda. Mr. Fishman has kindly made available for the authors' inspection samples of Communist propaganda mailed in bulk into this country at various times during the operation of the program. 
point of entry, albeit the biggest, volumewise, for all foreign mail coming into this country. ${ }^{21}$

Many members of Congress, particularly those on committees which had long been alert to detect Communist or alleged Communist dangers in our midst did not long remain ignorant or passive. Nor did the officials of the executive branch in close contact with the situation simply sit by as all this propaganda began swelling our Post Offices. As a consequence of both congressional pressure and sua sponte executive action, the present program of confiscation of foreign Communist propaganda took shape.

The Deputy Collector of Customs at New York became concerned in 1950; he called attention to the situation in New York and asked superiors whether any provisions of the new Internal Security Act of 1950 (relating to labeling of mail by domestic Communist organizations) ${ }^{22}$ were intended to affect all this Communist propaganda coming in from abroad. And, if so, what was his responsibility. For a while the answer-and customs and postal policy-remained uncertain. But customs officials began examining much of the material to see if they could exclude it as "advocacy of treason" under the Tariff Act." Admittedly they could not, but this did permit closer surveillance. Federal Bureau of Investigation agents were notified about recipients who seemed to be getting propaganda in substantial quantities, and some of the more noxious items were simply "strong armed," to use the words of a customs official. ${ }^{24}$

Meanwhile, a Senate subcommittee had been investigating domestic disseminators of Communist propaganda. Attention initially seems to have been focused on the "informational" activities in this country of various diplomatic representatives of Communist bloc nations. The committee had also become interested in the operations of Four

21. Hearings Before the Subcommittee To Investigate the Administration of the Internal Security Act and Other Internal Security Lawes of the Senate Committee on the Judiciary, 82d Cong., 1st Sess. 64-65 (1951).

22. 64 Stat. 987 , as amended, 50 U.S.C. $\$ 841$ (Supp. V, 1958).

23. 46 Stat. 688 (1930), 19 U.S.C. \$1305(a) (1952).

24. See Hearings To Investigate the Internal Security Act, supra note 21, at 63-64: "MR. STEPHENS. I might say what we have done is within the last 2 or 3 years. We have sent out circular letters to all collectors of customs, confidential circulars, you might say, instructing them on this border-line stuff where we don't feel we have a real law to seize it, to detain it, and submit it to the nearest Federal Bureau of Investigation and let them come in and have a look at it, and if the Federal Bureau of Investigation Officer in the district feels that it should not be released, we more or less strong-arm it to prevent it from going and then the stuff we are releasing we are furnishing the Attorney General on a quarterly basis with the name and address of the people that are receiving that material in reasonably large quantities, not every individual case, but if one individual or one organization in a community is receiving a constant flow of it, we furnish that information to the Attorney General and he, in turn, can invoke his Foreign check. ..." 
Continents, Inc., a New York importer of quantities of publications of all sorts from Iron Curtain countries. Why, the committee wanted to know, were these outlets-the diplomatic staff members and the commercial importers-exempted by Government officials from the labeling requirements of the Foreign Agents Registration Act? (Who in the State Department had persuaded the Department of Justice to adopt a "hands off" policy with respect to the dissemination of propaganda by members of the Russian foreign service? Who in the Justice Department was responsible for an unofficial "agreement" allowing Four Continents, Inc. to circulate Russian publications without any label disclosing their propaganda content? Had Judith Coplon, then an employee of the Department of Justice in the Foreign Agents Registration Section, exerted an improper influence here?) These seem to have been the questions of initial concern. ${ }^{25}$ But as the committee inquired into them its attention was drawn to the quite different problem of what to do about all the foreign Communist propaganda which was coming into this country via New York for direct distribution to American addressees. Conditions were then investigated at other points where foreign mail was entering the United States. Finding that similar problems existed, the committee applied informal pressure on postal and customs officials for more effective counteraction. Eventually the House Un-American Activities Committee came into the picture and applied similar pressure. ${ }^{26}$

Meanwhile, the Attorney General's Office advised harassed postal and customs officials that the Attorney General's ruling of 1940 was still "the law." 27 Postal, customs and Justice Department officials then arranged a program to intercept and confiscate Communist propaganda pursuant to this interpretation of the statutes. The activity was undertaken without direct congressional authorization, without much preparation in advance, without promulgating any rules of procedure or directives which the public at large could read.

There was, however, consultation with the interested congressional committees and some publicity of the menace of the Red propaganda threat through their hearings. Indeed, though the legal theory and

25. For background information as to the development of the committee's interest, see 99 CoNG. REc. app. 3249-56 (1953) (reprinting a series of articles from the New Bedford Times). See also Hearings Before the Subcommittee To Investigate the Adninistration of the Internal Security Act and Other Internal Security Laws of the Serate Conmittee on the Judiciary, 82d Cong., 1st Sess. at v-ix (1951).

26. For published hearings on this subject of the House Un-American Activities Committee, see sources cited note 75 infra.. For the close liaison between the UnAmerican Activities Committee and enforcement officials, see Hearings Before the House Committee on Un-American Activities, 85th Cong., $2 d$ sess. 2425-27 (1958).

27. See Hearings To Investigate the Internal Security Act, supra note 25, at 61. 
:operational plan of an anti-propaganda program came through the executive branch, much initial impetus was furnished by these committees. $^{28}$ Even after the program was well under way and well understood, the House Un-American Activities Committee continued to hold hearings in various places throughout the United States, calling up the same Government officials for substantially the same testimony, expressing continued shock at the disclosures made, urging postal and customs officials to redouble their efforts, assuring them that clear-cut legislative authority would soon be supplied so that they would know that it was clearly lawful to do what they were doing.

The scope of the legal power which the Post Office, Justice and Treasury Departments proceeded to carve out for their enforcement officials was broad. In legal theory, their program seemed to call for impounding any "political propaganda" sent here "in aid of a foreign government" by any one suspected as an unregistered "agent" of any "foreign principal." None of these limitations seems to have amounted to much when it came to propaganda from Communist countries.

The agency requirement was readily satisfied. As noted, a "foreign principal" is defined, roughly, as any person, organization or government outside the United States; and, subject to exceptions which may simply have been ignored, anyone acting for a foreign principal could be deemed an agent. Indeed, the Department of Justice later ruled that all political propaganda originating in Iron Curtain countries could be presumed to come from an "agent." 29

So, too, with the requirement that the agent send papers "in aid of a foreign government." If his papers are "political propaganda"

28. See id., 83d Cong., 1st Sess. 229 (1953): "Mr. Arens [counsel for the committee]. Mr. Fishman, without in any sense undertaking to throw bouquets at ourselves, it is a fact, is it not, that the drive against this political propaganda coming into the United States stems basically from the emphasis given by the Internal Security Subcommittee of the Senate a year ago? Mr. Fismisan. I think that is quite clear that it was considerably stimulated. MR. ARENS. Prior to the time that the Internal Security Subcommittee got into this, there were great areas in which there was nothing being done? Mr. FismMan. That is right."

29. Treasury-Post Office Memorandum. It should be noted that the Foreign Agents Registration Act as amended exempts certain persons otherwise classifiable as "agents" from the requirement that they register and label propaganda. 52 Stat. 632 (1938), as amended, 22 U.S.C. $\$ 613$ (1952). Among the persons exempted are: accredited diplomatic officers engaged in "activities which are recognized by the Department of State as being within the scope of the functions of such officer" $(\S 613(a))$; persons engaging in certain "private, nonpolitical, financial, mercantile, or other activities in furtherance of the bona fide trade or commerce of such foreign principal" ( $\$ 613(\mathrm{~d}))$; persons engaging "only in activities in furtherance of bona fide religious, scholastic, academic, or scientific pursuits or of the fine arts" (\$613(e)).

The Government apparently has taken the position that presumptively none of these provisions apply to persons in Iron Curtain countries who mail "propaganda." Apparently the view is that once a person, otherwise classifiable as an agent, disseminates propaganda he removes himself from the exemption provisions noted above. See Hearings Before Subcommittee No. 3 of the House Committee on the Judiciary on H.R. 4105 and S. 1273, 84th Cong., 2d Sess. 1416 (1956). 
then they are in "aid of a foreign government," advised the Government's lawyers. And what is "political propaganda"? The Registration Act defines it as:

"any . . . expression . . . reasonably adapted to . . . prevail upon, indoctrinate, convert, induce; or in any other way influence a recipient or any section of the public within the United States with reference to political or public interests, policies, or relations of a government of a foreign country or a foreign political party or with reference to the foreign policies of the United States or promote in the United States racial, religious, or social dissensions. . . ." 30 .

The breadth of this authority, the absence of any modus operandi planned in advance to enforce it, the absence of any published procedures including the absence of any notification to addressees of propaganda material, the emergency character of the operation and the novelty of the whole problem - these and other factors caused immediate, serious problems.

\section{The Confiscation: Program in Operation}

Efforts to stop the flow of Communist propaganda from foreign sources began in 1951 and were steadily augmented thereafter. ${ }^{31}$

The attempt was made to set up some sort of screening operation at every major point of entry for foreign mail. But the procedures were hasty and improvised, nor were there enough men everywhere to do the job properly-as at St. Paul where a warehouse full of material accumulated while a non-Russian speaking customs employee, furnished solely with a Russian-English dictionary, attempted to select and detain all publications deemed to contain "Communist propaganda." 32 Furthermore, the legal authority invoked to engage in such censorship was both broad and presumably difficult for local postmasters to understand. The objectives of the program were neither well formulated nor well understood among the very men charged with enforcement.

The criteria for "propaganda" were so broad that enforcement officials in the field were able to find suspect matter in Soviet published works on art, religion, philosophy, nineteenth century literature and even so apolitical a subject as Chess for Beginners; volumes of this kind

30. 56 Stat. 250 (1942), 22 U.S.C. $\$ 611$ (c) (5) (j) (1952).

31. See note 20 supra.

32. Hearings Before the Subcommittee To Investigate the Administration of the Internal Security Act and Other Internal Security Lazes of the Senate Committee on the Judiciary, 82d Cong., 1st Sess. 230 (1951). 
were detained even though they had been published prior to the Czar Nicholas' demise. ${ }^{33}$

Having once started a program of confiscating Communist propaganda, it was easy for the enforcement authorities to lose sight of what, presumably, was their basic objective-preventing the use of the United States' mails for mass dissemination of propaganda by foreign, Communist controlled agencies. The power which Attorney General Jackson had marked out in 1940 sometimes seemed tantamount to a power to impound any book coming from any foreign country if it contained the proscribed ingredients. So it came to pass that at least some officials in various Post Offices in the field were stopping suspicious publications from Hong Kong and India, and then France, Germany, England, and Canada, and withholding those which seemed to have a "propaganda type" message. 34

33. Most of these books were later cleared. Chess for Beginners, together with a number of other titles, was listed as a work which had been examined and ruled to be outside the "purview" of the Foreign Agents Registration Act. Hearings To Investigate the Internal Security Act, supra note 32, at 256. For reforms in the screening criteria, see text at pp. $644-49$ infra.

34. A few examples of detention or confiscation of non-Iron Curtain publications should be cited to show both the existence of this activity and the confusion among postal and customs officials over the scope of the program.

Copies of the book Five Stars Over China were sent to a number of individuals in the United States, from the author, a resident of Toronto, Canada. On several occasions shipments of the book were seized without notice. In another instance, the Postmaster of Newport, Vermont replied to an inquiry from one of these recipients that the book was "political propaganda within the meaning of the Foreign Agents Registration Act and was seized therefore by this office. . . " (Information on these incidents has been drawn from the files of the American Civil Liberties Union.)

A graduate student attending a large state university ordered, from England, some German language editions of works by Karl Marx, including an edition of his correspondence for the period 1844-1883, and various philosophical writings. These were seized. After seeking the assistance of his Senator, the student learned, several months later, from the Post Office, that the books had been destroyed in a big city Post Office as nonmailable. (Information taken from files of American Civil Liberties Union.)

A Vermont bookseller reported to the authors in 1955: "We have not been notified by the Customs that the 10 copies of the [Journal of Oriental Studies] are being held, but we hear from the University of Hong Kong, who are still trying to have the material released, that 'New York seems to consider Hong Kong as Mainland and not a British Crown Colony with a largish U. S. consulate staff who would be impounded by the People's Government were Hong Kong Mainland.' " (Information and correspondence furnished by the importer.)

In 1955 copies of the London Economist were held up for screening by the postal officials. See Time, Aug. 15, 1955, p. 33. In its edition of August 6, the editors of the Economist inserted a message to "Our Subscribers in the United States" explaining that the journal was being held up "as possible propaganda matter" and that delay in delivery was inevitable since the United States Customs authorities were "considerably in arrears" in their work. Concluded the Economist: "[W] feel that comment by us on this state of affairs might be in bad taste and certainly superfluous." Responding to queries about the Economist incident, the Solicitor of the Post Office told Congressmen that he "almost literally jumped out of [his] seat" when the incident was reported to him; it was further reported that the Solicitor "blamed [the incident] on 'some over-officious underling' and said that there had never been attempts to examine [the Economist or] any standard English newspaper or magazine for 'propaganda content." Washington Post and Times Herald, Oct. 10, 1955, p. 1 . 
Indeed, books which admittedly were neither pro-Communist nor anti-United States in theme, but which still seemed to be "propaganda" under the statutory definition, were occasionally stopped. Thus, a United States importer ordered, from England, Avro Manhattan's Catholic Imperialism and World Freedom. The thesis of this decidedly controversial book is that the Church, through Rome, is attempting to win political hegemony over the whole world. Here, declared the Postal Solicitor, justifying his decision to ban the book in the language of the statute itself, was a work "designed to promote in the United States, racial, religious and social dissensions." And, if the book did fit the statutory definition of "propaganda," of what consequence should it be that this propaganda was not Communist propaganda? ${ }^{35}$

Of course, most of the material seized was Communist propaganda from Soviet bloc countries, and most of it was sent here unsolicited by Communist controlled agencies, and the destruction of most of it went unnoticed and unlamented. But there were still thousands of Americans and many organizations who, for one reason or another, had ordered publications from Communist countries which contained patent propaganda.

For example: a number of important American research libraries gradually came to the conclusion that many items in the vast variety of Russian, Czech, Polish and Chinese materials on current events and cultural developments which they had been regularly receiving on an exchange basis were no longer coming through; there were gaps in the collections; some of the missing materials were irreplaceable. Specialized departments of universities, e.g., those dealing with Russian or Slavic affairs, as well as similar non-university agencies experienced frustrating losses. Numerous political scientists and free-lance writers and other experts on current events or current shifts in the "party line" behind the Iron Curtain failed to receive current journals and newspapers such as Pravda, which were of the utmost importance to their work. Bookstores and importers who sought to acquire Russian materials could not. Ironically, a consignment to one importer who was purchasing Soviet publications for United States military agencies was confiscated and lost. Mathematical Revieze, one of the world's three publications which list all known works in the mathematics field, was deprived of Russian titles for a year. The Association of American Geographers was moved to adopt a resolution expressing concern "over the government's policy of withholding distribution to competent

35. An account of this incident appears in Church and State Review, March 1955 , p. 2; id., May 1955, p. 2 . Our information on the case has been supplemented through correspondence with the British exporter of the book, the American importer and with the organization, Protestants and Other Americans United. 
scholars and libraries." Similar protests emanated from similar groups. And not only did the confiscation program result in widespread loss of material needed, it also produced great delays which were frustrating per se. ${ }^{36}$

: - The total impact of this censorship on American culture, science and research during this period can hardly be estimated in any quantitative way. The American people were soon to be sputniked into recognition that they had a lot at stake in maintaining, at least for those who were interested; the most liberal kind of access to information about the 'Communist world.' It would seem unnecessary, here and now, to labor the point that what happened from 1951 to 1955 was unfortunate and undesirable as a matter of national policy-even if that policy is to be formulated in terms of the most narrow national selfinterest.

Those dangers became apparent to postal and customs officials too. Repeatedly they made ad hoc concessions to meet some obvious imperative demand for a special dispensation. . But, since the statutes and the Attorney General's ruling gave no guidance, they were forced to go ahead on their own, first making empirical rulings for special cases, later, and gradually, developing general criteria applicable to all cases.

Thus, unwritten law developed during the period 1951-1955 which curtailed the scope of the Attorney General's ruling. The exclusionary -program came to be limited to more patent Communist propaganda, sent unsolicited and in quantity from behind the Iron Curtain or Communist controlled agencies outside it. To elaborate, the power to impound came to depend on three administration criteria, nowhere explicit nor even implicit in the Attorney General's ruling; these tests had to do with: (1) the character of the addressee of the material, (2) the source of the mailing, and (3) the character of the material.

\section{The Character of the Addressee}

As a result of the urgent complaints by many scholars, librarians and others, it was soon perceived that at least some addressees should be allowed to receive otherwise nonmailable "propaganda." The

36. See note * supra outlining the scope of field studies conducted in connection with this report. Our information on libraries is based on responses to a letter questionnaire to the member libraries of the Association of Research Libraries and other major libraries in the United States. Many libraries which have been significantly affected have furnished copies of correspondence with the Post Office. Our information on university departments, scholars, importers and bookstores, etc., is based on similar case files developed through correspondence and interviews with the individuals affected. Information on the Association of American Geographers and the magazine Mathematical Review has been drawn from the files of the American Civil Liberties Union. See also N.Y. Times, June 19, 1955, p. 27, col. 2. 
administrators of the program first tried to build up a list of persons and institutions in this category. It became known among some circles as "the white list." In some instances, people or institutions, were able to get on it by simply pestering the Post Office or the Bureau. In some cases the Post Office initiated the exemption process. . Thus, where publications addressed to a university or one of its departments 'were being withheld, a letter was sent to the institution's president. Typically it read:

"Parcels containing Communist propaganda arriving by mail from [an Iron Curtain country] and also from other countries are addressed for delivery to the University of ............ Such matter is nonmailable pursuant to an opinion of the Attorney General ... . unless addressed to a registered agent of a foreign government or to members of. diplomatic staffs. However, exceptions have been made in certain cases where such matter was addressed to universities which undertake to study such propaganda and, of course, in no way promote its dissemination. Some institutions of learning have stated that they have no use for such publications, do not desire to receive them and have not ordered or agreed to receive them:

"This office would appreciate a statement from you as to whether the University of..$\ldots \ldots \ldots$ desires to receive these Communist propaganda publications and the nature of their utility to the university and what restrictions are placed upon their accessibility.

"As you no doubt know, Communist propaganda has greatly increased in volume and viciousness and is being addressed to many persons and institutions which object to receiving such matter. It is believed to be incumbent upon this Department, therefore, to obtain some information as to the position of addressees of such publications where exceptions to the general rule of nonmailability are made." 37

All of the presidents (about whom we have any information) asked - some far more emphatically than others-that all publications be forwarded at all times. Some pointed out that all materials, regardless of content, might prove to be essential to further the study and research of members of their faculties. Some indicated the vital nature of this

37. Our field investigations and copies of correspondence furnished to us by a number of university librarians indicate that this letter apparently was sent to all universities whose libraries were receiving materials which postal and customs officials thought were subject to confiscation. The officials of one prominent university were reluctant to give out any information or copies of correspondence had with the Post Office during this period; they openly expressed concern about cooperating with this study lest the university lose its special exemption as a result. This occurred in 1956; they apparently were under the impression that their library was receiving privileges not accorded to others. 
research-in several cases it was Government sponsored research. Some pointed out that their libraries had broad exchange arrangements with comparable Russian institutions and had no way of knowing in advance what would eventually be worth keeping. Several librarians, answering for their institutions, were eloquent on functions of a research library, and they proceeded to lecture the Post Office on the need for uninhibited access to publications of all kinds at all times. Spokesmen for other institutions, however, were almost apologetic about asking for release of the propaganda. The president of one state university assured postal lawyers that all materials sent to his school would be segregated, under security protection, in a locked area of the library stacks.

Aside from universities, the Post Office also directed letters to a few, selected individuals asking whether Communist propaganda addressed to them should be delivered. Anti-Communist George Sokolsky responded angrily.

"The theory of your advice is that I am entitled to special privileges. But I do not like privileges. I want these publications because I subscribed to them. They can do me no greater harm than some American publications I buy. If I am to be saved from my reading habits I do not want it done by the Post Office, the business of which it is to deliver the mails." 38

Sokolsky appears to have articulated eloquently the feelings of others who discovered that the Post Office was policing their mail. And he was right in characterizing the exemption as a "privilege." At the time he wrote not everyone was allowed access to contraband propaganda, and very few were informed that they could enjoy the opportunity. It is hard to say what criteria were used to grant the privilege. But clearly, at this earlier stage in the program's evolution, some people who wanted mail from the Communist world and who asked for prompt delivery were still denied it.

One person reports that he was told by the Post Office that he was not sufficiently "educated." 39 Several faculty members were obliged to have their college presidents "clear" them with the Post Office before their publications were delivered. ${ }^{40}$ Other scholars changed the delivery

38. Sokolsky's letter was published in The Saturday Review, April 23, 1955, pp. 9-10.

39. This individual states that he contacted the Bureau of Customs and was told in reply: "They said I didn't have enough education to get them [Russian and Chinese magazines]." Information on this case was drawn from the files of the American Civil Liberties Union.

40. Two university teachers, one in Connecticut and one in Wisconsin, responding to our request for information gave this report. 
address from their homes to their university offices, whereupon publications previously witheld began to appear. ${ }^{41}$ Some journalists and free-lance writers went through a long, frustrating series of communications before interruption of their mail ceased. Some were told that there would be an "investigation" before there could be any clearance. ${ }^{22}$ A retired Coast Guard officer in New England had developed a unique avocation: studying various navigation problems confronting the Russian navy, using all sorts of current Russian magazines (even a fashion journal) to get his data. Learning that some people were allowed to receive such mail, he asked for the same privilege. The request was denied. He was told by his local postmaster that he was deemed "unqualified" to receive the propaganda he wanted. ${ }^{43}$ A midwestern technical library of long standing, had to receive "special clearance," apparently because postal officials were unfamiliar with its operations and standing. ${ }^{44}$ Ironically, when Customs did try to facilitate the entry of some "bona fide" subscriptions to various Communist journals by requesting commercial importers (who acted as agents for subscriptions) to furnish lists of persons and institutions from whom they had received orders, these importers refused to divulge the information. ${ }^{45}$

There is not sufficient space here-nor is there really need-to relate other painful incidents which marked the evolution of this policy of granting exemptions. What is important is the lesson: when Government officials, simply in the exercise of an unregulated discretion, tried to pick and choose among Americans as to who might and who might not receive Communist tinged publications, there was chaos.

The enforcement officials perceived this. Gradually it was recognized that anyone who ordered Russian materials ought to get

41. Two university teachers wrote to us that customs officials specifically requested them to change their mailing address (for publications sent from Iron Curtain countries) to their university offices.

42. A free-lance writer and journalist (whose field of expertise is Russian affairs) furnished us with copies of his considerable correspondence with postal and customs officials, reported that he experienced constant losses during a period ranging from 1952 into 1955. Copies of his extensive correspondence with postal and customs officials reflect his difficulties. He wrote more than a dozen times to Bureau or the Post Office seeking release of materials confiscated. His case exemplifies the difficulties experienced by dozens of others in securing release and uninterrupted delivery of materials needed to pursue professional activities.

43. Information on this incident was furnished to us by the individual involved.

44. Information on this incident, including copies of correspondence with the Post Office Department quoted above, was furnished to us by the library.

45. Information furnished through interviews with the President of Four Continents, Inc. of New York, the leading importer of Russian publications in the United States. 
them. The only thing the Government need worry about was the importer who acted as`a mass disseminator himself. Ironically, loopholes in the Registration Act sometimes. seemed to enable such.individuals to escape its registration requirements.

The policy of permitting entry of solicited materials was fixed by the end of 1955 but not generally known. Some persons still experienced inordinate delays and even occasional losses. Criticismmuch of it based on misunderstanding-continued. The Department of Justice finally promulgated its rule 6 in December 1956, which "codified" the informal policy already established by customs and postal officials. ${ }^{46}$ This rule declared, by implication, that the Government was permitting transmittal of propaganda to persons who have "ordered . . . or otherwise solicited such material." ${ }^{47}$ In practice it appears that anyone (other than a domestic disseminator) is entitled to receive foreign Communist propaganda if he requests it-even if the material was not ordered in advance.

Notwithstanding the literal terms of rule 6 , the Government still occasionally exercises outright censorship controls against at least some addressees-persons who are not registered (nor, necessarily, required to register) under the Foreign Agents Registration Act, but who import propaganda material in bulk for general distribution to the public at large. For example, a San Francisco bookseller who has imported books and tracts of all sorts and sometimes in substantial quantity (e.g., 100 copies of one. publication) reported repeated interference from postal and customs authorities, and this difficulty has continued into 1958. The prolonged detention (and in some instances destruction) of this importer's materials has probably been based on the Government's belief that he is a domestic distributor; and because he is he falls outside the purview of exemptions permitted under rule

46. 28 C.F.R. $\$ 5.6$ (Supp. 1958). For examples of criticism and continued misunderstanding as of July 9,1956, and a somewhat confused statement of policy on exemptions by the Solicitor of the Post Office Department, see Hearings Before Subcommittee No. 3 of the House Committee on the Judiciary on H.R. 4105 and S. 1273, 84th Cong., 2d Sess. (1956). These hearings were on a bill proposed by the Department of Justice simply to codify the Attorney General's opinion. See text at p. 653 infra. Strong opposition from the Librarian of Congress, the American Library Association, the American Book Publishers Association, the American Civil Liberties Union, and the American Friends' Service Committee persuaded the Post Office to withdraw its approval of the bill. Subsequently the Solicitor wrote to the Chairman of the Committee, suggesting a bill substantially similar to the text of rule 6 . The bill was never pressed thereafter, but rule 6 was promulgated a few months later.

47. The text of rule 6 (28 C.F.R. $\$ 5.6$ (Supp. 1958)) is as follows: "Any person not within the United States who uses the United States mails, or any means or instrumentality of interstate or foreign commerce, within the United States to circulate or disseminate political propaganda to addressees who have not ordered, subscribed to, or otherwise solicited such material shall be regarded as acting within the United States and as subject to sections 2 and 4 of the Act." (Emphasis added.) 
6.8 A Chicago importer who maintains à "peace library" and sells or distributes "peace" literature of all sorts-including propaganda tracts put out by Communist controlled agencies-reports continued losses; recently postal authorities have told him that he will not be permitted to receive "large quantities" of propaganda materials because rule 6 prohibits admittance of materials, whether solicited or not, if they are sent here in quantity for broad domestic distribution. ${ }^{49}$ Other persons or organizations have reported similar difficulties. ${ }^{50}$ The precise line which is to be drawn here-the line delimiting controls imposed upon suspected domestic disseminators-has not been articulated publicly. Libraries are apparently free to import what they want, even though the material is thereafter made freely available to the public at large. Individuals are apparently free to import a few copies of a tract, have it copied and redistribute it on a broad basis. Registered agents are entitled, presumably as a matter of law and not just administrative discretion, ${ }^{\text {s1 }}$ to receive all material, even when quantities of a single item are sent; and it is, admittedly, most difficult to police their domestic distribution to assure their compliance with the labeling requirements of the act. Notwithstanding these loopholes, the Government still appears to assert the right to control the volume of propaganda received by potential domestic disseminators who are not registered nor required to do so.

Apart from the more or less ad hoc controls exercised against these suspected domestic disseminators, mail is supposed to go to all who really want it. But there is still one, big, practical qualification-a procedural matter which affects the substance of rule 6's exemption in favor of "solicited" mail. Notices are not regularly sent as a matter of course to every individual addressee whose mail is stopped. That is impossible, say the administrators-pleading administrative impossibility and expense. Hence, if a person wants mail, other than first-class mail, from Soviet bloc countries, he must take it upon himself

48. Information on the San Francisco bookseller incident has been furnished by the importer himself, and by the Staff Counsel for the American Civil Liberties Union of Northern California. Additional information has been drawn from the ACLU files in New York. The ACLU dropped plans to litigate this case.

49. Information on this case, including copies of correspondence with the General Counsel (formerly Solicitor) of the Post Office, has been furnished by the importer.

50. The American Civil Liberties Union reports a similar pattern of controls against importations of the "Chicago Council for American Soviet Friendship." Apparently plans for litigating this case were dropped when copies of materials detained were released and the issue was thought to be "mooted." See 38TH ANNUAL REPORT OF THE AMIERICAN CIVIL LIBERTIES UNION 10 (1958).

51. See 52 Stat. 631 (1938), as amended, 22 U.S.C. \$§611-12 (Supp. V, 1958). See also Hearings Before the House Committee on Un-Anerican Activities, 85th Cong., 1st Sess. 1536 (1957) (quoting Mr. Fishman: "They [registered Foreign Agents] may import propaganda by the ton and have no restriction other than to [label what is disseminated here and report to the Attorney General]"). 
to request our Post Office for delivery; for, absent any information about the addressee, the enforcement officials may be unable to tell whether a suspect item is "solicited." They may send him a notice with a postcard asking if he wants this particular "propaganda" publication. If they send no notice and conclude the material is unsolicited propaganda, the addressee will never see the publication..$^{51 a}$

\section{Source of the Mailing}

While criteria exempting "solicited" materials emerged only after many (and often painful) case incidents, criteria exempting nonIron Curtain materials were developed more sharply, late in 1955, largely as the result of one case incident-the Post Office's dealings with the American Friends' Service Committee. ${ }^{52}$

In furtherance of some of its many, varied activities the Friends' Service Committee imported, from time to time, political pamphlets on various subjects from various sources in England. Among the publications ordered in 1955 were 500 copies of a leaflet called Guatemala: The Fate of a Small Country. This work-which condemned United States involvement in the Guatemalan revolution-had been published by the "Movement for Colonial Freedom," a British organization which counted approximately sixty members of Parliament among its number; and one was author of the pamphlet.

In the spring of 1955 the Committee asked the Movement why the Guatemala pamphlet had never arrived in the United States. The response from England: the pamphlets were mailed long ago; we are asking our Post Office to investigate; if an explanation is not forthcoming "within a week," we "will arrange for the question to be raised in Parliament."

The British postal officials did report: the pamphlets had been seized by the United States Government. Upon further inquiry to Washington, the Committee learned that "foreign propaganda" mailed from abroad was subject to seizure here, that the Guatemala pamphlet was in this class because (in the words of the Post Office) it stated that "there is no Communist threat there [in Guatemala], and that what took place was solely to benefit 'American big business.' " The Committee also learned that a number of other English pamphlets, which

51a. But see note** at p. 666 infra.

52. A full account of this incident appears in Hearings Before Subcommittee No. 3, supra note 46, at 45-51 (testimony of Mr. Winslow H. Osborne who acted as counsel for the committee). Our information about this incident has been supplemented through interviews with representatives of the American Friends' Service Committee and through examination of correspondence relative to the incident sent to us by the Committee. 
had been sent (some unsolicited) to its Boston office were under detention.

A series of inconclusive negotiations with postal officials followed. The Committee was on the verge of suing the Government-an unusual step for this group, when the Postal Solicitor suggested another conference; indeed, he took the novel step of coming to Philadelphia to facilitate the meeting. With characteristic candor the Postal Solicitor admitted that a lawsuit might play havoc with the Government's program which, he declared, should be aimed at unsolicited vast volumes of Red propaganda from the Soviet bloc, and not at propaganda from other foreign sources. Furthermore, the Geneva conference was now pending; United States and Russian officials were soon to bargain over relaxing controls upon the channels of communication between the two countries. The United States' position, he suggested, would be embarrassed if a lawsuit challenging its power to control Russian propaganda were to become a matter of public record, now. The Solicitor promised to release the pamphlets if the suit were dropped. But the Committee insisted he do more. It was not enough to give special privileges to one group. The same privileges should be accorded to all Americans similarly situated. Furthermore, some procedures should exist to supply notice and opportunity to be heard to those whose mail was stopped.

The upshot of the conference was this: the Committee called off its lawyers; the Post Office released all impounded materials, and promised, through its Solicitor, to revise the procedures for dealing with mail from non-Soviet bloc countries. Henceforth, there would be no detention of such mail unless the addressee was furnished with notice and an opportunity to claim the material detained. The Solicitor went on to assure the Committee that the Government's design was simply to exclude Communist propaganda sent here in quantities from Communist controlled agencies. Since few of these were, presumably, located outside the Iron Curtain, the occasion for screening any mail from any non-Communist country would be slight. The understanding was, in effect, reduced to writing through a series of letters. The Solicitor even submitted a copy of the form of notice which he proposed to use in cases where "non-Iron Curtain" propaganda was impounded.

Thus, as a result of all this bargaining, the Post Office renounced powers which, in theory, it enjoyed under the terms of the Attorney General's ruling; the substantive scope of United States censorship was reduced-delimited, virtually, to Iron Curtain mailings; procedural reforms were instituted to apply in the cases of non-Iron Curtain mailings. 


\section{The Character of the Material}

Publications emanating from the Communist world have varied greatly as to style, content and level of intellectual appeal. ${ }^{53}$ Typical examples of propaganda include: People's China, a well written, slickpaper, English language, Peiping-published fortnightly with articles and pictures portraying lavish social "progress" in Communist China and the "idealism" of her leaders; New Times, a weekly published in Moscow, in various languages including English, expounding the Communist position on issues of the day, linking the interests of the Communist bloc with the world's new, neutral countries; Soviet Woman, blending politics with fashion, news, sob stories, dress patterns and biographical homilies; Women of the Whole World, a similar English language monthly (published in the Soviet sector of Berlin) with perhaps more emphasis on the international questions of the day; World Youth, a Hungarian monthly, and World Student News, a Czechoslovakian monthly, directed at students everywhere with "news" of international conferences, ecstatic descriptions of the life of youth in various Communist and neutral countries and invitations to enlist in various "peace" crusades; and News, an English language Soviet monthly, sounding the tocsin for international exchange and damning United States "opposition" to such proposals.

Some tracts, such as Lenin's Boyhood and Adolescence (a primer on the "noble Lenin") and the laboriously titled The Just Fatherland Liberation War of the Korean People for Freedom and Independence, seem to bog down under the weight of their own words. Others have been sharp and hard-hitting, with clever cartoons or plausibly distorted conclusions drawn from reasonably accurate facts: thus, USA in Wort und Bild, a German language publication, used, inter alia, a collection of American comic book covers and pictures and an article on juvenile delinquency reprinted from the New York Daily Mirror to launch its attacks on American life.

In lesser numbers there have been tracts purporting to document United States war atrocities in Korea-often replete with pictures, sometimes written in English, sometimes in foreign languages.

53. The descriptions of materials which follow are based on our own inspection of what were said, by customs officials, to be typical specimens of propaganda which has been sent here in quantity. For a detailed listing by title of propaganda of this nature which has been seized under the program, see Hearings Before the Subcommittee To Investigate the Administration of the Internal Security Act and Other Internal Security Laws of the Senate Committee on the Judiciary, 83d Cong., 1st Sess. 232-56 (1953). See also Otten \& Seib, Red Mail to United States Jumps 2,500 Per Cent, Nations Business, July 1954, p. 46. Occasionally "propaganda" movies have been seized. Most of the Russian pictures imported for general commercial exhibition in the United States are imported by registered agents. 
From time to time customs officials have also stopped vast quantities of so-called "Back to the Homeland" mailings-first class letters sent to persons of foreign ancestry, particularly in areas around New York, Philadelphia and Detroit. ${ }^{54}$ While, individually, each seemed to be a personal communication from someone in Russia, Poland or East Germany to someone in the United States, it was perceived that these letters fell into a definable category. External appearances were enough to arouse suspicion: the handwriting and stationery were similar; the letters arrived in quantity. Once opened (after the addressee consented to inspection) ${ }^{55}$ the content of the communications also proved similar: the writer, allegedly a friend or kin of the addressee, urged defection-often physical return to the "Homeland," sometimes a donation of money. Sometimes (so customs officials state) this plea was coupled with veiled threats to members of the addressee's family still living abroad.

Many of these letters, along with the other propaganda described above, and indeed almost any publication from Russia, were seized or detained during the early years of the program. For all mail from the Iron Curtain was closely screened; and while attempts were made to make discriminations, to release materials deemed devoid of propaganda, gross mistakes obviously occurred. Thus, as has already been indicated, not only more patent "propaganda," but books and journals of every sort-some utterly lacking in any possible propaganda overtones-were seized and destroyed: texts on law, literature and science, editions of Russian classics and so on. ${ }^{58}$

54. On "Back to the Homeland" material, see, e.g., Hearings Before The House Committee on Un-American Activities, 84th Cong., 2d Sess. 96, 4705-18, 6055-56, 6070-71 (1957).

55. First class sealed mail has, in legal theory, been treated as subject to fourth amendment restrictions against searches and seizures ever since Ex parte Jackson, 96 U.S. 727 (1878), where the Supreme Court in clear dictum stated this rule. Other unsealed mail, domestic or foreign, is treated as subject to inspection regardless of the consent of the sender or addressee. See also 18 U.S.C. $\$ 1717$ (c) (1952) (one of the provisions of the Espionage Act upon which the Attorney General's ruling is constructed): "No person other than a duly authorized employee of the Dead Letter Office, or other person upon a search warrant authorized by law shall open any letter not addressed to himself."

Customs officials screening mail from abroad for any contrabrand material (obscenity, narcotics or foreign propaganda) inspect unsealed mail at will. But in the case of first class, sealed mail, they do not. However, whenever it is believed that first class mail contains contrabrand matter-whether it be narcotics, obscenity, lottery tickets or foreign propaganda-the suspect item is withdrawn and a notice sent to the addressee requesting permission to inspect. Unless permission is granted the material will not be delivered. See sources cited note 54 supra for discussions of this practice.

56. The dilemma of censorship and the confusion over what kind of propaganda to confiscate is aptly reflected in the treatment accorded the Russian newspaper Pravda. Here, presumably, was patent propaganda. Yet from the outset postal and customs authorities must have learned that many if not most people getting single copies of Pravda (and similar, established newspapers) were subscribers, aware of the source and nature of the publication, and most who read the paper did so because 
These obvious abuses probably occurred because there were, during this period (1951-1955), inadequate procedures for reviewing and

they wanted (and perhaps needed, as a professional matter) to know what went on in Russia.

The case for clearing Pravda as self-identified propaganda was neatly-or archlystated by a university teacher and constituent of the late Senator Joseph McCarthy. (The teacher has furnished us with an account of this incident and copies of the correspondence.) He wrote to the Senator: "It seems to me, Senator, either that somebody in a high advisory position in the Post Office Department is being too, too clever, or that some high administrative officials have lost their heads. If the decision does not derive from crypto-Communist activity, then it is the first real symptom of hysteria in this country. After all, who reads Pravda and Izvestia unofficially? How many copies actually come here?

"When we look at the problem realistically, Pravda and Izvestia are labeled; they are not effective instruments of Communist propaganda in America. Nor would they be any more effective if they came in far greater numbers than they actually do. One sincere New York Times article advocating "co-existence" (Sunday, July 4, 1954 issue) is a stronger instrument for furthering the crypto-Communist doctrine of co-existence in this country than all the openly published Communist papers in Russian and English put together." Senator McCarthy's reply was interesting: "I agree with you that it would be rather ridiculous to destroy copies of Pravda and Izvestia. As you indicate, both are clearly labeled for what they are. A sizeable number of people who want to keep abreast of what the Communists are advocating, and to follow their thinking on international issues, feel they need to read the Communist publications.

"I frankly did not know about this action on the part of the Post Office Department, but will take it up with Mr. Summerfield personally. I feel that one issue of a paper or a magazine which has the reputation of being a real American publication but which has been taken over by Communists and fellow-travelers (and there are many such) can do more damage than a thousand issues of Pravda and Izvestic." The Senator was informed by the Post Office Department: "In reply I may state . . . that copies of the said publications are going to subscribers thereof as far as the Post Office Department and the Customs Bureau are concerned" And, perhaps to allay any fears that postal authorities were "being too clever": "I am enclosing a copy of an article from Nation's Business entitled 'Red Mail to U. S. Jumps 2,500 Per Cent,' which I believe you will find of interest."

This Post Office letter was dated April 1955. It was not wholly accurate. There is abundant evidence that many copies of Pravdo were confiscated during the period 1952-1955. During the early months of 1955 the Johns Hopkins School of Advanced International Studies reported delays and losses which hampered instruction and research. (Information furnished through correspondence with its Dean.) Other subscribers did too.

Was Pravda nonmailable? Or was it to be treated as Senator McCarthy urged? Said the Post Office to an interviewing journalist in the early part of 1955: "There's nothing new about it. We've been banning Pravda and Izvestia for years, since long before my time. . . it's all perfectly routine." See Kahn, Abe Goff, Our Chief Censor, The Reporter, May 19, 1955, p. 12. Another lady wrote in February 1955 demanding to know why she was not receiving her copies. Replied the Solicitor: "Many mailings of Communist propaganda received from abroad, including Pravda, have been withdrawn from the mails and disposed of as non-mailable matter." (Information and correspondence on this incident were furnished by the subscriber.) In March 1955 (see the Washington Post and Times Herald, March 18, 1955, p. 1), it was reported that no less an anti-Communist than Rep. Francis Walter of Pennsylvania had "blasted" the Post Office's Solicitor for failure to deliver Pravda and Izvestia. Walter is quoted as saying: "If I had the power to do it, I would have every copy [of these newspapers] translated and delivered through the United States. . The reading of these two sheets convinces every thinking person of the abysmal fraud perpetrated [by the Communists]." In August the Postal Solicitor assured another Congressman that "so far as the Post Office and Customs Service are concerned, copies of Pravda and Izvestia are going to subscribers thereof." Information and correspondence furnished by Rep. Frank Thompson of New Jersey. However, other subscribers have reported continued delays to us. In 1956 the Government, in an unofficial communication to us, stated its official position as follows: "Foreign language publications [such as Pravda] published in the country of origin primarily for domestic consumption are considered as self indicative of their source since they indicate the 
supervising activities of overzealous men in the field, an inadequate staff of translators and knowledgeable readers, a tremendous backlog of publications placed under detention and a hazy conception of the objectives of the program. Moreover, the problem of what kind of propaganda to seize was aggravated when customs and postal officials began screening, sporadically, publications sent from non-Iron Curtain countries; this activity produced more abuses.

Eventually some rulings of postal or custom officials, such as the banning of Avro Manhattan's Catholic Imperialism and World Pozerer, the detention of the London Economist and the seizure of the American Friends Service Committee's pamphlets caused considerable public criticism and embarrassment. In these and several other cases, the Solicitor of the Post Office was obliged to apologize for the mistakes of "underlings" or himself confess error-which he would do with admirable candor. These incidents occurred during the latter quarter of 1955 , and the notoriety seems to have spurred postal and customs officials directly responsible for the program to reappraise their objectives and procedures.

As we have seen, policies were effected to permit release of publications to persons who requested delivery, and shortly thereafter attempts to screen non-Iron Curtain mailings were largely abandoned. Similarly, efforts were made to narrow the range of censorship of publications coming from Iron Curtain countries, to contract the standard defining nonmailable propaganda. ${ }^{57}$

Gradually, there was a relaxation of bans once put upon a number of Soviet-published books. Thus, historical and scientific texts, works of literature and art, and other materials which once were seized or detained regularly, came to be released without inquiry as to whether they were solicited-simply on the theory that their propaganda content was not noxious enough to warrant their exclusion. Generalizations are difficult and risky, but it would appear that most of the propaganda seized today consists of contemporary, mass-produced materials designed for mass distribution here to promote some current Communist claim.

country of origin and the organization publishing them. They are generally delivered promptly to all addressees [without regard to any inquiry whether the addressee solicited the materials]." Treasury-Post Office Memorandum.

The history of the treatment of Pravda-whether to ban it as nonmailable foreign propaganda-is an interesting reflection of the difficulty in defining the objectives of the antipropaganda program and the confusion experienced during the period when enforcement officials tried to work out a program of exemptions.

-57. See Hearings Before Subcommittee No. 3, supra note 46 , for public criticism of the program before a congressional committee and for an explanation by the Post Office's Solicitor of attempts made to limit the program. 
Administration of all these various reforms and criteria for exemption were facilitated by the development of more centralized operating procedures. All mail originating from behind the Iron Curtain was sent, directly upon arrival, to one of three "Segregation Centers" which were established in New York, Chicago and San Francisco. There teams of translators and inspectors, operating under the guidance of the Deputy Collector of Customs of New York, screened the material. Suspect matter was referred to the Deputy Collector either by physical shipment or by a resume of the contents. His decisions were reviewed, more and more only as a matter of form, by the postal lawyers. Through the close supervision of this official, many defects in operating procedures causing delay as well as mistakes in decisionmaking have been corrected.

Thus, the pattern of seizures has contracted considerably and the exclusionary program appears to be limited to more patent forms of Communist propaganda, mailed in quantity from behind the Iron Curtain or from Communist controlled agencies in the non-Communist world and sent unsolicited to people in this country or sent in volume to suspected disseminators in this country who are not registered here as foreign agents. ${ }^{58}$

The impact of this program today in terms of interference with the activities of most people who seek access to publications from the Communist ruled world is probably slight. But there are still irritating delays and occasional unexplained losses. ${ }^{59}$ And there is deliberate

58. Postal and customs officials whom we interviewed have assured us that this has long been their objective. However, only since 1956 has criticism of the program abated.

59. In 1957 we inquired of every research library which had previously reported delays or losses to us asking whether material sent to them was now being withheld or delayed. Those replying stated that so far as they could ascertain, materials were coming through regularly. But see Ruggles, Governmental Restrictions: Soviet and American (Association of Research Libraries Slavic and East European Project: Study of American Library Resources and Needs, Mimeographed First Draft Memorandum, July 25, 1958), indicating continued concern over the program. It is also clear that delays or mistakes causing total loss do still occur in the case of noninstitutional subscribers of material.

One college professor reports (as of April 15, 1958): "During 1957 I kept a steady record of the receipt by me of People's China and have compiled these dates in a list on page 2 in a comparison with the dates on which the same issues were received by the . . . University Library. Also, I have added the dates on which my copies were mailed in the Hong Kong Post Office. My record covers 20 issues so far received, with the exception of 3 issues that I did not bother to record. My last 4 copies for 1957 have not yet arrived.

"If one compares the dates of arrival in the . . Library with those sent to me, in only two cases did mine arrive earlier, both by about 3 weeks, and both on the same dates in both cases, although the dates of issue are $51 / 2$ months apart!

"In the 15 other arrivals my copies were $1-2$ months later ( 5 issues) to 9-11 months later ( 3 issues). And recall that some of my copies were released only on my request (or protest) to the Post Office Department.

"I am not sure about claiming professional injury on account of these delays of my copies. It is certainly true that my course in Chinese Culture and Society suffered 
interference with some importers who do not and perhaps need not (under the statute) register as foreign agents, but who do receive quantities of publications from abroad. ${ }^{60}$ And, of course, so long as notice of seizures is not given to every addressee, it is probable that many Americans can never know for sure whether publications addressed to them are being seized by the Government and committed to oblivion with or without their approval.

\section{Problems of Legality}

Thus far the administrators of this program have escaped a direct challenge of the legality of the operation. In the beginning, potential litigants whose materials were seized and not released even upon request were either too uninformed or otherwise unwilling to assert their rights. More recently materials have been released to any individual complaining of interference; thus, once a complaint is made, the injury is usually rectified, and the complainant seldom suffers further injury apart, perhaps, from delay. And, since postal-customs enforcement officials will now permit delivery automatically wherever they have reason to believe the propaganda is desired-except in the rare case where the recipient is a mass disseminator-it may be hard to find a plaintiff with "standing" to test the legality of the confiscation program. ${ }^{\text {"I }}$

and also that my own research and professional interests have been held back by these delays. However, if I claim 'professional injury,' the PO can once more assure me that since I do have a 'professional interest,' they will in the future release my copies promptiy instead of piling them up and even opening them and re-sealing them, as they have been doing now for some time."

60. See text and notes at notes $48-50$ supra.

61. This note treats more fully the problems of standing to challenge the legality of the present exclusionary program.

Presumably such a suit would be brought under 28 U.S.C. $\$ 1339$ (1952) and would seek declaratory and injunctive relief holding the program, as codified in rule 6, 28 C.F.R. $\$ 5.6$ (Supp. 1958), to be illegal and unenforceable. An obvious potential objection to this suit would be that under prevailing practice and rule 6 the plaintiff is entitled to receive publications he wants for himself, and having asked for these propaganda publications he will receive them; consequently he cannot assert sufficient injury to himself as the basis for his suit. See Joint Anti-Fascist Refugee Comm. v. McGrath, 341 U.S. 123, 149-51 (1951), and cases cited therein. Nor can plaintiff assert possible losses to other addressees as the basis for his own demand for relief. See, e.g., Tileston v. Ullman, 318 U.S. 44 (1943).

Conceding the difficulties here, the Government may still find itself confronted with a suit by a plaintiff who would have "stariding." Consider the following cases, which are framed hypothetically, but which, we believe (from correspondence and interviews; see also notes 58-60 sipra), are based on quite possible situations.

Case 1. $\mathrm{P}$ is a university professor whose field of interest requires continuous up to date information on political and cultural developments in Russia. The Post Office, pursuant to rule 6 , now delivers Communist propaganda publications to $P$, although to secure delivery $\mathrm{P}$ was obliged to contact the Post Office and request it. $P$ sues to enjoin enforcement of rule 6 alleging as his injury that as a result of the illegal program (enforcement of rule 6): (1) his mail from Russia is delayed because it must be processed through the segregation centers, and these delays, sometimes consuming many weeks, impair his proficiency in his field of work; (2) he has, in the past, been subjected to the unnecessary burden of identifying himself as a 
Yet the Attorney General's ruling of 1940, the basic legal authorization for the operation, does rest on weak legal ground. Recall

person who wants delivery of propaganda publications, and he will probably be subjected to further, similar burdens in the future by virtue of the need to contact Post Office officials concerning future delays in delivery; (3) he faces the continuing increased possibility of loss of publications addressed to himself because enforcement officials may erroneously conclude that these materials are unsolicited; moreover, he has no assurance that all materials sent to him from the Communist bloc will be delivered, e.g., publications which he has not ordered in advance may be sent to him; and if this material should be seized in the United States, $P$ would have no information of the seizure and therefore no way of objecting to it. Perhaps other similar injuries could be alleged. The "standing" questions might be whether on its face P's complaint alleged enough injury, and, if so, whether the injury alleged could be proven. To prove these "injuries" $\mathrm{P}$ might well have to rely on testimony of Government officials since they are the only persons familiar enough with the program to testify about the mechanics of its operation and the possibilities of delay or loss. We assume, absent a privilege, the officials would have a duty to disclose, candidly, these facts. See United States v. Reynolds, 192 F.2d 987, 995 (3d Cir. 1951), rev'd, 345 U.S. 1, 9-10 (1953). Assuming P's complaint is not dismissed out of hand, his case might well prove to be one where the issue of standing becomes so inextricably related to the question of whether on the merits there has been a denial of his legal rights, that the courts would proceed to treat the merits of P's substantive allegations. $C f$. NAACP v. Alabama ex rel. Patterson, 357 U.S. 449 (1958).

Case 2. $\mathrm{P}$ is a bookseller specializing in foreign imports. $\mathrm{P}$ is not registered tnder the FARA. From time to time $P$ imports books either for general resale or for customers. $P$ alleges delays as a result of the program (as in case 1 above) and alleges that as a result of these delays he has lost customers and may continue to do so. Depending on the factual strength of these allegations $P$ might well have standing. See the discussion in Mr. Justice Frankfurter's opinion in Joint AntiFascist Refugee Comm. v. McGrath, supra. Compare Public Serv. Comm'n v. Wycoff Co., 344 U.S. 237 (1952).

Case 3. $\mathrm{P}$ is an organization of scholars who need access to publications of all sorts from Communist bloc countries. ' $P$ sues in its own behalf and in behalf of member scholars who wish to receive all materials sent to them from the Communist bloc but who do not wish to identify themselves to the Post Office to request delivery, because this requirement, allegedly, is an illegal interference with the members' rights to receive publications which they desire to read; and the imposition of this burden is an injury serious enough to give the organization standing to assert the invalidity of the program in behalf of its members. Presumably $P$ would be met with the argument that it cannot assert rights personal to its members. Tileston v. Ullman, sipra. An effective answer might be that if $\mathrm{P}$ cannot assert these rights of its members (to be free from the burden of identifying themselves in order to receive alleged "propaganda") then there is no real way to protect the very rights which the members are asserting. $C f$. NAACP v. Alabama ex rel. Patterson, 357 U.S. 449, 458-60 (1958). ("To require that it [i.e., the right personal to the members to withhold information about their Association] be claimed by the members themselves [rather than the organization] would result in nullification of the right at the very moment of its assertion." Id. at 459.) Again it might be urged that $\mathrm{P}^{\prime}$ s interests (e.g., promotion of information about Russia) are so closely related with its membership that $P$ should be allowed to assert violation of its members' rights as a basis for attacking rule 6. Cf. Pierce v. Society of Sisters, 268 U.S. 510 (1925); Barrows v. Jackson, 346 U.S. 249 (1953).

As to all of the cases cited above, cf. Frankfurter, J. in Joint Anti-Fascist Refugee Comm. v. McGrath, supro at 156-57: "[T] he inference [can] be drawn from the cases that 'standing' to challenge official action is more apt to exist when that action is not within the scope of official authority than when the objection to the administrative decision goes only to its correctness. . . . The objection to judicial restraint of an unauthorized exercise of powers is not weighty."

In addition to the above cases, the policy and practice of forbidding potential disseminators from importing publications in quantity might well produce a litigable case. Consider the following: $P$ imports Communist propaganda publications on disarmament and other subjects in quantity for use in his "peace library" and in connection with his advocacy of a change in United States policy. $P$ is not registered as an agent under the FARA and apparently has no contacts with any foreign 
the reasoning of that opinion: (1) it is a crime for a domestic "foreign agent" not to register; (2) the mailing of foreign propaganda by an unregistered agent is therefore a crime under the Espionage Act ("knowing control" of "papers" in "aid of a foreign government" used in "violation" of "any penal statute"), and (3) under the Espionage Act, papers used in violation of that statute are "non-mailable"; (4) the act of a "foreign," foreign agent in mailing or otherwise sending propaganda from abroad to recipients within the United States is equally a violation of these various statutes because use of the United States mails equals physical presence and activity as an unregistered agent, here, and therefore (5) "propaganda" mailed by "foreign," foreign agents is nonmailable and can be destroyed. ${ }^{62}$

That this reasoning found little support in the history, theory or express terms of the Foreign Agents Registration Act (FARA) as it stood in 1940 has already been discussed. ${ }^{63}$ And the case for the program was further weakened perhaps unintentionally when, in 1942, Congress amended the FARA. ${ }^{64}$ The legislative history of these amendments reflects, apparently, only one passing reference to the Attorney General's ruling in a committee hearing. ${ }^{65}$ So it is difficult to assert that Congress actually was aware of the problem of "foreign," foreign disseminators, let alone that it ratified the ruling calling for the exclusion of their propaganda.

In terms, the act, as amended, provided-and it now provides:

"Every person within the United States who is an agent of a foreign principal and required to register under the provisions of

principal other than the placing of orders for various publications. $\mathbf{P}$ is advised by the Post Office that he will not be permitted to receive these materials "in large quantities," and if "large quantities" are sent to him only "several copies" of "each publication" will be delivered; this decision is based on an interpretation of rule 6, viz., that it is a prohibition against admittance of materials into the United States for broad dissemination. (The facts of this case are framed on an incident reported to us by a Chicago importer who has also furnished copies of his correspondence with the Post Office) Clearly in this situation $P$ should have suffered sufficient injurythe loss of his publications-to supply standing. There might be some difficulty as to the scope of the questions $P$ could raise and the scope of relief which could be granted. For example, if the court found no statutory authority for rule 6 as applied to $P$ (or that the rule is unconstitutional as applied), would the court go further and hold that rule 6 cannot be enforced in any respect? $\mathbf{P}$ might well be able to secure relief going that far since a determination of the question whether rule 6 has any statutory basis would seem necessarily involved in the adjudication of P's claim for personal relief. But constitutional questions related to the validity of rule 6 might well be treated as separable. Cf. Ashwander v. TVA, 297 U.S. 288, 345-48 (1936) (Brandeis, J., concurring). But cf. Thornhill v. Alabama, 310 U.S. 88 (1940).

62. See text accompanying notes 12,13 supra,

63. See text accompanying notes 14,15 supra.

64. See note 18 supra.

65. Hearings Before Subcommittee No. 4 of the House Committee on the Judiciary on H.R. 6045, 71st Cong., 1st Sess. 51-52 (1941). 
this [Act] and who transmits ... . in the United States mails . . any political propaganda [a term which is defined elsewhere] ..."

must file copies of that propaganda with the Library of Congress and the Attorney General and must also label it in accordance with detailed requirements. ${ }^{66}$

Since these provisions apply to persons within the United States, the Department of Justice has, presumably, been unable to rely upon them. ${ }^{67}$ So, in effect, it apparently has ignored the amendments and simply reiterated the Attorney General's ruling-and this notwithstanding the fact that the act now contains express provisions dealing with the mailing of propaganda by agents, that these provisions promote the disclosure objectives of the original act with no suggestion that censorship was intended as an additional sanction.

To be true in logic to its premises, the Department of Justice is obliged to say that unregistered foreign agents outside the United States may send no propaganda, labeled or not, into the United States. But that conclusion is unacceptable precisely because it is unrealistic; the law can not be pushed that far; Government spokesmen admit there should be no objection to propaganda sent by "foreign," foreign agents if it fits the various administrative exemptions which have been created, and these exemptions are justified on the ground that they added.)

66. 52 Stat. 632 (1938), as amended, 22 U.S.C. \$614(a) (1952). (Emphasis

67. On the other hand, the Department of Justice might point to 56 Stat. 255 (1942), 22 U.S.C. $\$ 614$ (c) and particularly (d) (1952) to support the position that the 1942 amendment codified the 1940 opinion. These subsections authorize the forwarding of "foreign prints" which are "prohibited entry" by $\$ 1305$ of the Tariff Act, 46 Stat. 688 (1930), 19 U.S.C. $\$ 1305$ (1952), or $\$ 1717$ of the Espionage Act, 18 U.S.C. $\$ 1717$ (1952), to the Library of Congress. The argument appears to be that these two subsections indicate congressional recognition that not only material advocating treason, insurrection and forcible resistance to the laws of the United States (expressly cited in those statutes), but also foreign political propaganda (as included by the Attorney General's opinion interpreting the FARA) is denied entry into the United States.

Congress, it may be argued, dealt in the 1942 amendment only with propaganda mailed by "domestic" foreign agents; it was content to rely upon the Attorney General's opinion excluding propaganda sent into this country by a "foreign" foreign agent, qualifying this only by subsections (c) and (d) permitting copies of this propaganda to be sent to the Library of Congress.

It is true that at one subcommittee hearing administration spokesmen stated that these subsections were required because of the Attorney General's opinion. Hearings Before Subcommittee No. 4, supra note 65 . It is also true that 18 U.S.C. $\$ 1717$ (1952) is one of the Espionage Act provisions invoked by the Attorney General in 1940 to justify his ruling that propaganda mailed by unregistered agents may be impounded. But the solitary reference to the Attorney General's opinion (which is not mentioned elsewhere in the debates or committee reports) and the ambiguous reference to $\S 1717$ hardly justifies ascribing this significance to the Library of Congress subsections. Surely it is more reasonable to assume that these were added to permit the entry and forwarding to the Library of Congress of materials advocating treason, insurrection and forcible resistance, rather than to find here a legislative basis for an administrative operation of such dimensions. 
are consistent with the basic labeling-disclosure objectives of the act. ${ }^{68}$ But the fact remains that these exemptions are inconsistent with the premises of Attorney General Jackson's opinion.

The intent to authorize a censorship operation of this kind should hardly be inferred from ambiguous statutory authority and negligible evidence of congressional purpose. Contrast, for example, the Tariff Act: here Congress has expressly excluded materials advocating treason or insurrection and the like; procedures for seizing these materials, for supplying notice and an opportunity for de novo court consideration of their contraband content are spelled out in the statute. $^{68}$ The Tariff Act is thus aimed at a species of subversive materials originating abroad, and it was only passed after long, arduous debate. But Congress has never debated the merits of excluding virtually all foreign "propaganda" or the necessity for having a law which would make the Tariff Act, for the most part, unnecessary. Surely, then, it stretches imagination to suggest that Congress passed the FARA with ancient ambiguous provisions of the Espionage Act in mind or to suggest that Congress anticipated Attorney General Jackson's legal gymnastics-to suggest that Congress chose such devious means to authorize a confiscation operation which might so significantly impinge on basic freedoms. ${ }^{70}$

Enforcement officials of the Postal, Treasury and Justice Departments have recognized their precarious legal position. Bills to confirm the Attorney General's 1940 ruling have been suggested. One was introduced and pressed by the Department of Justice in 1956. It passed the Senate without attention. But articulate spokesmen from various civil liberties minded groups unleashed a score of criticisms in the hearings before the House Judiciary Committee. Perhaps the most effective critic was the Assistant Librarian of Congress (speaking for the Librarian) who reviewed some of the unhappy history of the recent past and startled the Committee with the assertion that if the bill were to pass, books from the Oxford press or articles critical of our foreign policy in the London Economist might, in theory, be subject to summary seizure. The Post Office's Solicitor then testified to this effect: he really had not studied this bill too carefully; the job of preparing it had been delegated to the Justice Department; and he recom-

68. See Hearings Before Subcommittee No. 3, supra note 46, at 37-41.

69. 46 Stat. 688 (1930), 19 U.S.C. §1305 (a) (1952).

70. While in theory under international law Congress may have the power to require nonresident aliens to file registration statements here and label "propaganda," cf. AII, Foretgn Retations Law of The United States \$ 8 \& comments (Tent. Draft No. 2, 1958), the intent to prescribe such conduct regulating nonresident aliens should not be imputed to Congress "in the absence of clear indication to the contrary," $i d$. \$31. See also id. \$32 \& comments. 
mended that Congress drop the matter for the present-till more consideration was forthcoming from his Department. ${ }^{71}$

In the last session Congressman Walter introduced a bill to amend the FARA similar to those previously introduced-a bill which again would simply codify the Attorney General's ruling. ${ }^{\mathbf{2}}$ These provisions were inserted in the midst of omnibus legislation dealing with the Internal Security Act and related matters. In this posture these proposed amendments to the FARA might pass all too easily with all too little attention. If such legislation is introduced again-indeed whether or not such clarifying legislation is introducedCongress should examine carefully the necessity for authorizing the broad powers asserted today under the theory and terms of Attorney General Jackson's ruling. For there are also constitutional grounds for doubting the legality of this extension of censorship or any statute which in effect would simply codify and permit the administrative practices described above. These questions are considered next, but in the context of an analysis of the total problem of what Congress may do to meet the problem of foreign Communist propaganda in our mails.

\section{The Need for Review of the Propaganda Problem}

There is a real need for careful review at both the executive and congressional level of the question of what controls, if any, should be imposed upon dissemination of these publications.

Today's extensive, censorial, exclusionary program is based solely on an Attorney General's opinion issued in 1940. The legal validity of that ruling is clearly doubtful, and it is well to remember that the opinion was promulgated at a time of a world-wide, shooting war and directed in large part against "domestic" propagandists who were receiving quantities of Nazi propaganda for further distribution here. Enforcement of the ruling was completely abandoned after World War II-apparently in recognition that the principal justification was based on wartime necessity. Enforcement was only revived in time of war (the Korean conflict) and at a time when our fear of Communism's capacity to promote domestic subversion exerted strong influence on the activities of Government. The exclusionary program which evolved in the early 1950's seems in a large measure to have been the result of prodding from particular congressional leaders-members of the Senate Internal Security Committee and, later, members of the House Un-

71. See Hearings Before Subcommittee No. 3, supra note 46 . Subsequently the Solicitor did propose a bill-substantially a codification of "rule 6." See note 35 supra. Apparently, however, no effort has been made to press this proposal.

72. H.R. 9937, 85th Cong., 2d Sess. (1958). 
American Affairs Committee-who urged or encouraged officials in the Justice, Treasury and Post Office Departments to develop the operation. ${ }^{73}$

It would appear that the executive branch, while recognizing the dubious legality of the program, has never candidly reviewed its rationale in light of past experience and today's needs. Congressional review for these purposes has hardly been adequate. True, the Internal Security and the House Un-American Affairs committees have exposed some of the dangers or alleged dangers which might result if no countermeasures against foreign Communist propaganda were undertaken. But objective, comprehensive study from a broad perspective still seems needed-particularly in view of the lack of clear-cut authorization to the Post Office and the Bureau of Customs to do what they are doing. ${ }^{74}$ For it is poor precedent, indeed, for Congress to permit censorship of the sort now employed without a plain legislative mandate. Rather, because of the complexity of the propaganda problem, exercise of legislative judgment instead of abdication to executive officialdom seems particularly appropriate.

The fact is that the objectives of today's exclusionary program are unclear. What policies are we now trying to enforce? What policies should we enforce? Postal and customs officials have often said that the purpose is to prevent widespread distribution of undesirable propaganda to the public at large. Some enforcement officials have openly voiced the opinion that it would be dangerous to permit delivery of this propaganda to "the foreign born" or other segments of the population because it would promote disloyalty or subversive conduct. ${ }^{75}$ Usually coupled with this argument, though it is essentially a quite different proposition, is the economic justification: the United States Post Office and our Treasury should not be obliged to bear the expense of delivering vast quantities of the unsolicited prop-

73. See note 28 supra.

74. Congressman John Moss' Special Subcommittee on Government Information of the Committee on Government Operations and Senator Thomas Hennings' Subcommittee on Constitutional Rights of the Committee on the Judiciary have both explored the possibilities of investigation, but so far neither commttee has moved openly into the field. See note 81 infra.

75. See, e.g., Hearings Before the Honse Committee on Un-American Activities, 84th Cong., 2d Sess. 4705-20, 6069-72 (1957); id., 85th Cong., 1st Sess. 76, 273, 1539-40 (1957-1958). The Post Office has circulated, to members of Congress and individuals seeking information about the foreign propaganda program, many reprints of the article Red Mail to United States Jumps 2,500 Per Cent (supra note 53). This article, based on interviews with postal officials, stresses, inter alia, the argument that the propaganda may have a dangerous influence on the public at large, particularly to "Americans of foreign birth who still feel more at home reading their mother tongue or who still have ties with the old country." Otten \& Seib, supra note 53, at 46. See Hearings Before Subcommittee No. 4, supra note 65 , at $40-44$, where the Solicitor incorporated this article as a part of his official statement to the Committee. 
aganda of our cold war "enemy." 76 On other occasions it has been said that the purpose of the program is simply enforcement of a disclosure statute; if there were other ways to assure full disclosure of the source of foreign Communist propaganda materials in our mails (something more than a foreign postmark and publication dateline indicative of origin within a Communist controlled country), all mail could and should be delivered. ${ }^{77}$ It seems also to have been suggested that the exclusionary program is basically a foreign policy measurea retaliatory weapon which our country is using in the cold war: the Communist bloc has expended great efforts to propagandize the world in an aggressive way, violative of traditional, peacetime relationships between sovereignties, and our exclusion of this propaganda is a justifiable countermeasure regardless of any domestic threat posed by the influx of the material. ${ }^{78}$ Yet on only a few occasions does it appear that the United States ever has protested against the attempt of the Communist countries to flood this country with propaganda. ${ }^{70}$ Indeed, in the contexts of other international problems our government has taken a strong stand against censorship which would bar criticism of the government of one country by the people of another. ${ }^{80}$ Again, enforcement officials have sometimes justified the exclusionary program on the ground that this activity, along with other bans on international

76. See, e.g., Hearings Before the House Committee on Un-American Activities, 84th Cong., 2d Sess. 2442 (1957). Cf. the proposals by Congresswoman Katherine St. George to withdraw second, third and fourth class postage privileges from all communist propaganda, discussed in Otten \& Seib, supra note 53.

77. See e.g., Hearings Before the House Committee on Un-American Activities, supra note 76, at 6046; Hearings Before Subcommittee No. 3, supra note 46, at 11 .

78. Cf. the observations of Chairman Francis Walter, Hearings Before the House Committee on Un-American Activities, 84th Cong., 2d Sess. 5434 (1956).

79. See, e.g., 28 Dep'T State Bult. 578 (1953) (United States protest to Polish Embassy against distribution of anti-United States propaganda here).

80. Compare, for example, the position taken by the United States (in the United Nations) on the draft covenant on Freedom of Information. The United States has consistently opposed attempts by many other countries to limit the concept of freedom of information. Our position has been officially stated (by the United States Representative on the UN Committee To Draft a Convention on Freedom of Information) in these terms: "Freedom of information is the right of every person to have access to all available facts, ideas and opinions regardless of source, and not only to the information approved by his government or any party. It is his right to test the official pronouncements of his government against the opinions of his fellow citizens, and those held by other peoples; his right to advocate his belief through organs of his choice. It is his right to state his frank opinion of his public officials, and those of other governments as well. It is his right to communicate freely with his fellow citizens, and with those of other nations.

"We believe that the exercise of this freedom is the inalienable right of every person. We believe that this freedom belongs to that relatively small but vital area of the democratic process which must remain, as far as possible, immune from governmental interference. This is the absolute test of democratic government. To the extent that the exercise of this freedom is not free, no other liberty is secure." Quoted in Binder, Freedom of Information and the United Nations, 6 INTERNATroNAL ORGANIZATION 210, 222 (1952). 
contacts, is necessary if we are to be in a position to bargain with the Communist bloc countries over measures to be undertaken to ease their restrictions on the dissemination of American publications: we need the program as leverage to lift the Iron Curtain. ${ }^{81}$

Whether these various objectives are consistent or not, the factual bases to support them have hardly yet been fully adduced. For example, if, as is most usually asserted, today's exclusionary program is to be justified primarily on the ground that these controls are necessary to protect national security, then the assumed premise that the propaganda will have a harmful influence on many of its recipients should be examined carefully. Notwithstanding information revealed by the inquiries of the Un-American Affairs and Internal Security Committees and fears voiced by some of their members, it would seem advisable to learn more facts than we now know about the nature, quality and potential psychological impact of the various publications condemned..$^{22}$ If, as is also commonly asserted, the program is to be

81. In November 1955 the Solicitor of the Post Office told the Associate Counsel of the Senate Subcommittee on Constitutional Rights that, at the request of the Secretary of State, he would have to refuse to testify about the nature and methods of the postal-customs anti-foreign propaganda program. Discussion of the legality of the operation, said the Solicitor, would prejudice the interests of the United States at the forthcoming Geneva Conference. A similar statement was made to the "Moss Committee." As a result of the Solicitor's refusal to testify, both Committees postponed, indefinitely, hearings on this subject. Interview With J. Delmas Escoe, Nov. 16, 1955, who was, at that time, Associate Counsel to the Senate Subcommittee on Constitutional Rights.

It is not clear whether the bargaining position of the United States, to make arrangements for cultural exchanges with the Soviet Union, might be weaker if in fact our Constitution precludes any controls over Soviet propaganda mailed into this country. Apparently our diplomatic representatives have proceeded on the theory that the United States can control entry of such propaganda just as it can control entry of Soviet citizens. Over the past several years, with increasing frequency, the United States and the Soviet Union have arranged exchanges of publications, personnel, and programs of various kinds. The beginnings of this comprehensive exchange program can be traced to the conferences of the heads of governments in July 1955 and of the Foreign Ministers in October-November 1958. See generally 33 Dep't State Burc. 174-77 (1955); 33 id. at 774-86, 876-78 (1955). Following these conferences in January 1956, the Soviet Union agreed to permit the distribution in that country of the United States magazine Amerika in return for American acquiescence in the distribution of the Soviet magazine USSR in this country. 34 id. at 18 (1956). The Geneva conferences culminated in the United States-Soviet agreement of January 27,1958 , sometimes known as the Lacey-Zaroubin agreement. $38 \mathrm{id}$. at 381 (1958). For the text of the agreement see 38 id. at 243 . The implementation of this exchange agreement, $38 \mathrm{id}$. at 323,$381 ; 39 \mathrm{id}$. at 390 , has resulted in specific arrangements for the exchange of publications and TV programs, 37 id. at 119,386 (1957), films, 39 id. at 289,696 (1958); 38 id. at $248,552,830$, and national exhibits, $39 \mathrm{id}$. at 577 , as well as exchange of visitors from various fields. It is thus apparent that there has been progress in the exchange of materials, much of which obviously could be considered of a "propaganda nature." No one has as yet raised the question whether these arrangements, in whole or in part, are consistent with the policy or literal meaning of the Attorney General's ruling of 1940 as presently enforced.

82. If the assumption that this propaganda is dangerous to our security is true, then Congress may well wish to change the law insofar as it permits registered agents and members of diplomatic staffs to import this material without restriction. See 52 Stat. 632 (1938), as amended, 22 U.S.C. $\$ 613($ a) (1952). But see discussion note 
justified in part because of the expense of delivering the propaganda, it may still be advisable to learn more about these costs: how much expense is involved here? How does it compare with the cost of managing a censorship operation designed to prevent delivery? ${ }^{83}$ Similar questions might well be raised with respect to factual assumptions underlying other assumed objectives-if, in fact, there are other objectives to be secured.

Even if, after full review, it seems desirable to do something to counteract attempts of Soviet propagandists to use our mails for wholesale, direct dissemination of their publications, the question remainswhat specific countermeasures should be taken? We turn now to the examination of some possible courses of action, examining these in the light of limitations which the Constitution may impose on Congress' power to act at all.

\section{Legislative Alternatives and Constitutional Limitations on Congress' Power To Impose Controls}

Review of the problem may persuade Congress that some sort of legislative controls are necessary. The most likely argument for legislation might be as follows: propaganda is a major cold war weapon. The Soviet Union is said to have spent around three billion dollars a year to persuade, intimidate or otherwise win the war for men's minds; according to the estimate of one customs official, Sovietcontrolled disseminators sent nearly seven million pieces into this country in $1956 .{ }^{84}$ This propaganda takes all sorts of forms, some ridiculous, others noxious: the germ warfare tracts; the "Back to the Homeland" letters which apparently have caused no little misery among many recipients; foreign language tracts aimed, via specially worked up mailing lists, at the "foreign born" - these are some of the items

101 infra. Individuals in both these categories frequently import vast quantities of materials, and customs officials have frequently stated that it is very difficult to police later distribution to determine whether the importer-disseminator has properly labeled the material. See, e.g., Hearings Before the Honse Committe on UnAmerican Activities, 85th Cong., 1st Sess. 268-69 (1957).

83. In manpower alone the Bureau of Customs alone has been required to increase its staff appreciably at the several segregation centers simply for the purpose of processing propaganda. See, e.g., Hearings Before the House Subcommittee on Appropriations, 84th Cong., 1st Sess. 132 (1955) (requests for seven translators and seventeen clerks) ; N.Y. Times, July 7, 1954, p. 7, col. 1 (eleven more translators added to New York customs staff to augment present staff of five said to be "inundated" by "foreign Communist propaganda").

84. For a general discussion of Russia's world-wide propaganda drive see KIRKPATRICK, TARGET: The WORID; Communist Propaganda Activities in 1955 (1956). The estimate noted in the text was made by officials of the United States Information Agency in testimony before the House Un-American Activities Committee in 1957. See, e.g., Hearings Before the House Committee on Un-American Activities, 85th Cong., 1st Sess. 257-58, 270 (1957). 
which Government officials have most frequently cited in defense of their activities. With no controls, America must face, in theory, the prospect of an even more concerted effort to use our mails. Ironically, United States taxpayers pay a good part of the cost of this propaganda dissemination, for, under the terms of the International Postal Convention and international usage, the United States exacts no postage for the domestic transmission of foreign mail; ${ }^{85}$ we are obligated to carry it unless the content so offends our domestic law that the material is subject to confiscation. ${ }^{86}$ Thus, inaction will produce a situation where the United States, while spending billions of dollars to counteract Communism, is subsidizing the dissemination of our cold war enemy's propaganda here.

Assuming these considerations do persuade Congress to do something, the question remains: what specific countermeasures could be adopted? Initially, the range of choice seems wide-from an outright confiscation statute to one which provides for delivery of all mail, but with a stamp affixed to Iron Curtain propaganda which would simply indicate (over and above the foreign postmark) the geographical origins of the publications. However, there are constitutional limitations on the power of the Government to act in this field; these limitations may well narrow the choice available. ${ }^{87}$

1. A confiscation statute. One legislative choice would be enactment of a statute which, after reciting the dangers noted above, authorized confiscation of all foreign "Communist propaganda"-defining such contraband in terms similar to the existing FARA definition. (A statute with a censorship standard narrower than "Communist propaganda" would seem unnecessary since there already is one-the Tariff Act of 1930, which proscribes admittance of publications advocating "treason" or "insurrection" or "forcible resistance to any law" or threats to life. ${ }^{88}$ )

Enactment of a statute calling for confiscation of "Communist propaganda" would pose obvious policy problems : for example, preced-

85. See Universal Postal Convention, July 11, 1952, art. 77, [1953] 1 U.S.T. \& O.I.A. 1118, T.I.A.S. No. 2800 . Compare id. arts. $39,78,79$.

86. Id. art. $59(5)$.

87. For an excellent discussion of the constitutional implications of the exclusionary program as it was enforced in 1955, see Note, Govermment Exclusion of Foreign Political Propaganda, 68 Harv. L. Rev. 1393 (1955). We acknowledge, again, our debt to this writer.

88. 46 Stat. 688 (1930), 19 U.S.C. $\$ 1305$ (a) (1952). It is worth noting that when Congress passed this statute the Senate, sitting as a "Committee of the Whole," rejected broader standards defining subversive materials which might be subject to confiscation in large part because many Senators doubted that Congress had the constitutional power to go further. See 71 Cong. Rec. $4432-72$ (1929); 72 Cong.

REC. 5414-5520 (1930). 
ing discussion has already underscored the fact that thousands of Americans have professional need for propaganda publications, and frequently the need is related to national self-interest. Thus, constitutional considerations apart, such a statute would seem undesirable without exemption provisions; and to the extent exemptions were made discretionary Congress would be inviting censorial discriminations.

But passing these problems, an outright confiscation statute of the type described above, even if it contained provision for notice and hearing, would probably be unconstitutional. The argument for its validity might proceed from two alternative propositions:

1. The United States Government-via a combination of its power to control foreign commerce, ${ }^{89}$ conduct foreign relations ${ }^{90}$ (especially in time of "cold war" ${ }^{91}$ ) and establish a postal system with other countries-should have plenary power to exclude this brand of foreign propaganda. ${ }^{92}$

2. If the Government's power is not absolute, any balancing of interests ${ }^{93}$ would find the exclusion justifiable because of the potential adverse effect on American morale and upon the American fisc.

These arguments, we think, should be rejected. What is here involved is "propaganda"-ideas and arguments, distorted and noxious though they may be.94 The first amendment, with its use of the phrase "no law," is in terms a total limitation on governmental power to curb dissemination of political argument; at the very least it should impose some limitation upon governmental power, even where the "speech" be disseminated through the channels of foreign commerce by the post

89. Cf. e.g., Buttfield v. Stranahan, 192 U.S. 470 (1904); Weber v. Freed, 239 U.S. 325 (1915).

90. Cf., e.g., United States v. Curtiss-Wright Export Corp., 299 U.S. 304 (1936).

91. Cf. Dennis v. United States, 341 U.S. 494 (1951); Schenck v. United States, 249 U.S. 47 (1919).

92. Cf. Ex parte Jackson, 96 U.S. 727 (1878) ; Public Clearing House v. Coyne, 194 U.S. 497 (1904); United States ex rel. Milwaukee Social Democratic Publishing Co. v. Burleson, 255 U.S. 407 (1921). Compare Hannegan v. Esquire, 327 U.S. 146 (1946); Roth v. United States, 354 U.S. 476 (1957).

93. Cf. Dennis v. United States, 341 U.S. 494, 542 (1951) (Justice Frankfurter's concurring opinion).

94. See Roth v. United States, 354 U.S. 476, 484 (1957): "All ideas having even the slightest redeeming social importance-unorthodox ideas, controversial ideas, even ideas hateful to the prevailing climate of opinion-have the full protection of the [Constitution] unless excludable because they encroach upon the limited area of more important interests." 
office in time of cold war. The Government, having established the channel of communication, cannot open and shut it at will. ${ }^{95}$

We put to one side the question whether nonresident aliens have any right under the United States Constitution to use the United States mails to circulate propaganda. ${ }^{96}$ The question is whether the American addressee is given a constitutional right to receive this material. True, most cases construing the first amendment deal with the right to create, publish and disseminate. But these rights are protected, not for the sake of giving the dissident the right to speak in an empty room, but to curb political controls on political discussion and on the development of the arts and knowledge generally. The right to obtain publications should be as important under the rationale of our first freedom as the right to create and publish them in the first place. ${ }^{97}$ And under this rationale there should be no room for discrimination between ideas which are born abroad and those which find their origins in this country.

If Americans do have a first amendment right to receive publications, then a statute authorizing confiscation of "Communist propaganda" should abridge that right. The danger from distribution could hardly meet the "clear and present" standard or any variant traditionally used to measure the legality of such restraints, ${ }^{98}$ particularly since a form of "prior restraint" would be used here. ${ }^{99}$ Whatever definition Congress might assign to "Communist propaganda," the criteria would, perforce, be imprecise-in all likelihood too broad to permit the censors to exercise objective judgment as to whether material should be banned. ${ }^{100}$ On balance these restrictions on the right to receive mail

95. Cf. United States ex rel. Milwaukee Social Democratic Publishing Co. v. Burleson, 255 U.S. 407, 417, 436 (1921) (Brandeis, J., Holmes, J. dissenting). As Holmes put it: "The United States may give up the Post Office when it sees fit; but while it carries it on, the use of the mails is almost as much a part of free speech as the right to use our tongues. . . "Id. at 437 .

96. Cf., e.g., United States ex rel. Knauff v. Shaughnessy, 338 U.S. 537 (1950); Johnson v. Eisentrager, 339 U.S. 763 (1950); Galvan v. Press, 347 U.S. 522 (1954).

97. Cf., e.g., Marsh v. Alabama, 326 U.S. 501 (1946); Thornhill v. Alabama, 310 U.S. 88 (1940); Martin v. City of Struthers, 319 U.S. 141 (1943); Grosjean v. American Press Co., 297 U.S. 233 (1936); Meyer v. Nebraska, 262 U.S. 390 (1923). Compare also United States v. 31 Photographs, 156 F. Supp. 350,360 n. 40 (S.D.N.Y. 1957), where questions as to the Burean of Customs' constitutional power to exclude obscene publications from social scientist importers (who needed the publications for research) were raised but not decided.

98. Compare Dennis v. United States, 341 U.S. 494 (1951), with Yates v. United States, 354 U.S. 298 (1957).

99. Cf. Near v. Minnesota, 283 U.S. 697 (1931). See also Emerson, The Doctrine of Prior Restraint, 20 LAW \& CoNTEMP. ProB. 648 (1955).

100. Cf., e.g. Winters v. New York, 333 U.S. 507 (1948); Burstyn v. Wilson, 343 U.S. 495 (1952). The cases upholding broad controls over "obscene" publications (Roth v. United States, 354 U.S. 476 (1957)) or "group libels" (Beauharnais v. Illinois, 343 U.S. 250 (1952)) would seem distinguishable because of the judicial gloss put on the meaning of "libel" and "obscenity" and because of the distinction, whatever its merit, suggested by the Court itself, i.e., the distinction between "speech" dealing with ideas, politics, social conditions and so forth, and "speech" without any such "redeeming social importance." See note 94 stipra. 
and have access to publications should outweigh dangers asserted in justification for the statute, particularly since less drastic alternatives are available to accomplish the legislative ends. ${ }^{101}$

2. A statute providing for summary seizure of propaganda mailed from Communist controlled sources but for release of any publications to persons who come forward and request delivery. We envision here a statute largely codifying present practice, e.g., a statute setting out legislative "findings" on the menace to security as well as the burden of expense to our government if all propaganda were automatically carried and authorizing: (1) seizure of all Communist propaganda mailed from behind the Iron Curtain (and perhaps, too, if it be assumed the danger justifies it, all propaganda mailed by any foreign, Communist controlled groups), but, (2) requiring the Post Office to deliver any mail subject to seizure if an addressee or potential addressee notifies the Department of his desire to receive the materials or if postal officials otherwise conclude that the materials have been solicited.

In defense of such a statute it might well be argued that there is no constitutionally protected right to receive unsolicited mail, that the right to receive mail and have access to publications means only a right to receive material which the addressee wants and requests and that this right would be adequately protected by the statute.

But should there be such a distinction between solicited and unsolicited materials? A great portion of all mail daily received-of all information daily imparted by mail-is probably unsought $a b$ initio. The recipient receives this information without requesting it or knowing in advance that it is coming to him, but it would seem to be a part of his first amendment freedom to decide for himself what he wishes to do with it. Perhaps the addressee may have little "property interest" in this unsolicited mail. Perhaps he may have little desire for the publications after inspecting them. Yet, there is an interest worthy of protection here, and that interest is the freedom of Americans to read what they choose to read, and to enjoy the opportunity to exercise

101. Similar difficulties would probably invalidate a statute designed to prohibit outright and flatly the importation in quantity of propaganda. See discussion of this administrative practice in text accompanying notes 48-50 supra. Again, less drastic alternatives would be available to control domestic dissemination, e.g., by enforcement of existing sedition laws insofar as they can be constitutionally enforced (cf. The Communist Control Act, 68 Stat. 775 (1954), 50 U.S.C. \& 841 (Supp. V, 1958)) and by enforcement of laws requiring disclosure of an agency relationship between the disseminator and a foreign principal (which we assume may be constitutional if the law is not too broad, burdensome or vague; see United States v. Peace Information Center, 97 F. Supp. 255 (D.D.C. 1951). Cf. United States v. Harriss, 347 U.S. 612 (1954). Compare Staub v. City of Baxley, 355 U.S. 313 (1958), and also cases cited note 104 infra. 
that choice. ${ }^{102}$ This freedom, too, would seem basic under the rationale of free speech, and it may receive scant protection if addressees are given no right to exercise a choice to receive unsolicited mail. Surely it would be unthinkable for governmental officials to have the power to decide what pieces of unsolicited domestic advocacy Americans may receive; again there seems to be no persuasive basis, on this point, to distinguish between geographical sources of mail-domestic or foreign.

Assuming there is a right to receive all mail, solicited or not, the question is whether, on balance, the statute described above violates itwhether, under the first and fifth amendments, the procedure for enforcement of the statute must, at a minimum, make provision for informing an addressee of the existence of the propaganda publications and of his right to have them without question if he so requests.

Administrators of today's program have said (up to now) that a requirement of personal notice of that sort sent to every addressee would make enforcement most difficult: with millions of items to process, the manpower requirements and expense would be exorbitant. ${ }^{103}$ The situation, they observe, is to be distinguished from enforcement of other "nonmailability" statutes, e.g., those providing for seizure of "obscene" mail (the second largest area of postal censorship today), because the volume of this contraband is insignificant compared to the volume of propaganda. If true, these administrative claims should certainly be a factor to be weighed in deciding the statute's validity. Important, too, might be the extent to which alternative precautions were employed to supply a general notice of the terms of the law-e.g., by general publications in post offices and other places giving a clear explanation of procedures available to request delivery of mail.

To be weighed against these claims are the risks to freedom. In the first place, unless enforcement officials supply notice, how can they, themselves, know for sure whether material addressed to an individual is solicited and urgently needed? How can their assumption that material is "propaganda" be adequately tested? By resort to summary procedures they simply presume to make those decisions. No doubt, in practice, their assumption that the material is "propaganda" and is undesired and may therefore be seized has been true in most instances. But experience with the enforcement of the program has also shown that when notices have been sent, the addressees receiving such notices have frequently demanded that there be no interference whatsoever with the delivery of any propaganda addressed to them at any time. (Recall Mr. Sokolsky's eloquent protest. ${ }^{104}$ ) In the second place the

102. See, e.g., Martin v. City of Struthers, 319 U.S. 141, 143 (1943).

103. But see note ** at p. 666 infra.

104. See text accompanying note 38 supra. 
absence of personal notice procedures puts a burden on every American who wants to be sure of receiving mail addressed to him from anywhere behind the Iron Curtain; he must come forward and identify himself to some appropriate postal or customs official and have his name put on some list. This burden, viewed realistically, is in itself a deterrent to enjoyment of what we assume should be a constitutionally protected right. ${ }^{105}$ Apart from that, the person who does undertake the burden of notifying the Post Office can never be sure, absent notice of confiscation, that every item sent to him will be delivered; costly delays may occur; mistakes causing total loss of a publication desired can happen, and, since the Government can seize summarily, these delays or mistakes may easily go undetected. ${ }^{106}$ These considerations militate against the constitutionality of the statute described above and against the validity of today's program as codified in rule $6 .^{107}$

3. A statute which provides for seizure of "propaganda" but release to those who request release and which further provides for personal notice to all addressees prior to confiscation of propaganda. This statute would codify present practice but add the additional (and highly significant) requirement that no propaganda could be seized unless the addressee, after personal notification, waived his right to delivery. It may be urged, of course, that such a statute is economically and administratively unfeasible. But if feasible, would it be constitutional?

One serious charge which might certainly be leveled at the statute is that arguably it thrusts an unreasonable onus on many citizens who might otherwise choose to request delivery of propaganda; the fear of stigma (especially if the addressee has no scholarly, journalistic or similar interest in receipt of the material) might well deter many persons from exercising the right to receive this mail-a right which we believe must be granted, not simply as a matter of statutory dispensation, but as a matter of constitutional necessity. An invitation to identify oneself as a reader of Communist propaganda might well be regarded by many people as an invitation virtually to incriminate themselves. To the extent that this is true, Congress would thereby be creating a barrier to the free flow of information. ${ }^{108}$ Whether, on balance, the barrier would be regarded as so unreasonable that the Constitution would condemn it is much more doubtful.

105. Cf. NAACP v. Alabama ex rel. Patterson, 357 U.S. 449 (1958) ; Thomas v. Collins, 323 U.S. 516 (1945) ; American Communications Ass'n v. Douds, 339 U.S. 382, 402 (1950); United States v. Rumely, 345 U.S. 41, 46-47 (1953). Compare United States v. Harriss, 347 U.S. 612 (1954). See also cases cited note 101 supra.

106. Cf. note 59 supra.

107. 28 C.F.R. \$ 5.6 (Supp. 1958).

108. See note 104 supra. 
4. A statute designed to make the propaganda pay its own way. This statute would provide for the automatic delivery of propaganda once the recipient paid a "postage due" type exaction for its carriage within the United States. Here the principal (but not sole) justification for the statute is the economic argument-the United States taxpayer should not be required to pay the cost of delivering Communist propaganda in the midst of our present cold war situation. The legality of this statute under the Postal Convention may be dubious. ${ }^{109}$ Its constitutionality might also be doubtful. Clearly the exaction would have to be small or else the case becomes similar to the problem of the confiscation statute. But even if the exaction were small the question remains whether the courts would yield any exception to the principle that neither Congress nor administrators operating under broad, discretionary standards, can be allowed to single out unpopular categories of publications and levy even a small tax against their distribution. ${ }^{110}$ Perhaps, on balance, such an exception might be allowed, considering (1) the foreign source of the mail; (2) the circumstances of the cold war; (3) the economic burden of carrying tons of enemy propaganda. But the imposition of this "tax" on the distribution of "speech" together with the resultant burden ${ }^{111}$ on the addressee who desires to exercise his rights, could be a dangerous precedent. In any event, the cost and difficulties of administering such a statute might well make it selfdefeating.

5. A disclosure statute providing for automatic labeling and delivery of all mail. This statute would simply authorize officials to stamp publications mailed here from behind the Iron Curtain and believed to contain propaganda. The stamp would simply indicate the origin of the item; possibly it might go further and indicate that the materials were believed to contain "propaganda." 112

109. The Postal Convention provides that each administration shall retain in full the postage it has collected. Universal Postal Convention, supra note 85, art. 77. This is subject to the "Transit Charge" requirements (id. arts. 75, 79), which provide that the originating country must pay a "Transit Charge" to the intermediatenon-destination carrying country, based on weight, etc. Id. art. 78. The Convention of course permits any country to exclude mail which offends its domestic law, but it seems to make exclusion an "either-or" proposition. See also id. art. 59(5).

110. Cf. Grosjean v. American Press Co., 297 U.S. 233 (1936); Murdock v. Pennsylvania, 319 U.S. 105 (1942). See Hannegan v. Esquire, 327 U.S. 146, 156, 158 (1946) (Post Office not authorized by statute to withdraw second class privileges from magazine because content was deemed close to "borderline" of obscenity and not in public interest; Court declared that "grave constitutional problems" might be encountered were Congress to exercise such power). See also NAACP v. Alabama ex rel. Patterson, 357 U.S. 449, 461 (1958) (dictum on "taxes" which have "consequence of unduly curtailing . . . freedom of press").

111. See text accompanying note 104 supra.

112. This latter provision, however, would seem unnecessary and undesirable in that it would require government officials to act in a censorial capacity. 
If the sole purpose of the Foreign Agents Registration Act, the statutory basis for today's program, is disclosure, and if, as Government officials sometimes assert, disclosure is in fact the objective of the present program, then such a statute might well be all that is necessary. At least for an experimental period, such a statute might be attempted as an alternative to any type of greater censorship.

If a label of the sort described above is not enough to alert Americans and make them wary of the validity of messages in the publication, then the fabric of our democracy is far weaker than we think it is. A free and self-reliant people should be capable of the discernment needed to withstand dangers latent in the blasts or blandishments of Soviet manipulated propagandists. The risks and economic burdens resulting from having no restrictions other than an indication of the origin of the publication may be the cost of freedom; these costs may well be worthwhile if the gain is preventing a dangerous censorship precedent.**

** Subsequent to the preparation of the manuscript of this Article, postal and custom officials undertook, on an experimental basis, the task of supplying notice to all recipients of foreign Communist propaganda. A brief report on this development, plus some further observations on the program and possible legislative alternatives, will appear in the next issue of the Revieze. 